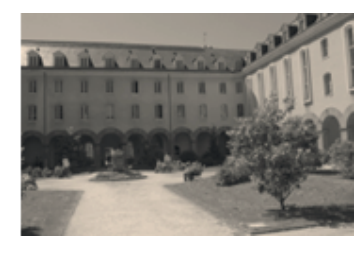

ELECTORAL COMPETITION AND POLITICAL SELECTION: An analysis of the ACTIVITy of French Deputies,

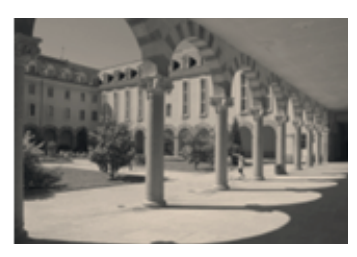
1958-2012

Nicolas GAVOILLE

Stockholm School of Economics in Riga, Latvia Condorcet Center, University Rennes 1, France

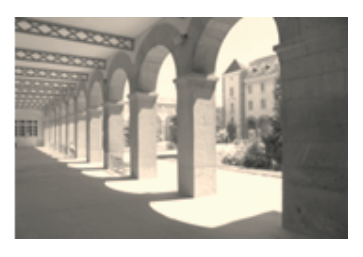

Marijn VERSCHELDE

EISEG School of Management, Department of Economics and Quantitative Methods, France, and Center for Economic Studies, Katholieke Universiteit Leuven, Belgium

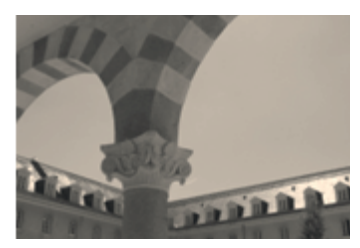




\title{
Electoral competition and political selection: An analysis of the activity of French deputies, 1958-2012
}

\author{
Nicolas Gavoille* $\quad$ Marijn Verschelde ${ }^{\dagger}$
}

\begin{abstract}
In this paper, we study the relation between electoral competition and political selection, using a unique dataset containing detailed yearly information about members of the French National Assembly from 1958 to 2012. First, we innovate by using activity as a proxy for politicians' quality. As we gathered information on the many aspects of deputies' individual work, we use a nonparametric composite indicator of deputy activity that fully acknowledges the multidimensional nature of parliamentary work. Second, we do not impose any assumption about the relationship between electoral competition and political selection by using a fully nonparametric framework. Third, this method allows studying the evolution of the relationship between electoral competition and political selection over time. Overall, our results show that deputies elected in a priori contested districts have a higher overall activity, with the intensity of this relationship reaching its peak in the 80 's but constantly decreasing since then.
\end{abstract}

Keywords: Competition, Election, Political Selection, Kernel Regression, Nonparametric Econometrics

JEL: D72, J45, C14

\footnotetext{
${ }^{*}$ Corresponding author. Stockholm School of Economics in Riga, Strelnieku iela 4a, Riga LV1010 - Latvia and Condorcet Center for Political Economy, Université de Rennes 1, Faculté de Sciences Economiques, 7 place Hoche, 35000 Rennes - France. E-mail : nicolas.gavoille@sseriga.edu

${ }^{\dagger}$ IÉSEG School of Management, Department of Economics and Quantitative Methods, Socle de la Grande Arche, 1 Parvis de La Défense, 92044 Paris La Défense cedex - France and Center for Economic Studies, Katholieke Universiteit Leuven, Etienne Sabbelaan 51, 8500 Kortrijk - Belgium. E-mail: m.verschelde@ieseg.fr.
} 


\section{Introduction}

Political economy recently rediscovered that individuals, and not only institutions, matter for economic outcomes (Besley et al., 2010; Dreher et al., 2009; Jones and Olken, 2005). This emphasizes the need not only to shape institutions in order to discipline incumbent politicians, but also to design efficient political selection mechanisms. Several theoretical determinants have been shown to affect political selection: the wage of politicians (Besley, 2004; Gagliarducci and Nannicini, 2013; Mattozzi and Merlo, 2008; Messner and Polborn, 2004; Poutvaara and Takalo, 2007), the transparency of politics (Mattozzi and Merlo, 2007), the institutional flexibility (Acemoglu et al., 2010), and reservation quotas (Besley et al., 2005, 2013). In addition to a well-known disciplining effect (Stigler, 1972; Becker, 1983 for instance), electoral competition is also likely to enhance this selection process, by pushing the competing parties to select candidates of higher quality in order to seduce sufficiently enough unaligned voters to ensure electoral success (Galasso and Nannicini, 2011).

This paper extends the empirical investigation between electoral competition and the quality of politicians exploiting a unique dataset focusing on the deputies of the $V^{\text {th }}$ French Republic, from its birth in 1958 to the end of the XIII ${ }^{\text {th }}$ legislature in 2012, covering more than 2,400 deputies for a total of 24,011 observations. The French National Assembly is an ideal testing ground for this in many respects. First, the institutional context remains (quasi) stable since 1958, allowing meaningful comparisons over such a long period. Second, this institutional stability is paired with a highly heterogeneous political context, with left-wing majorities following right-wing ones. Finally, this institutional context fits the theoretical framework of Galasso and Nannicini (2011), which we adopt.

We bring three main contributions to the literature. First, we provide for the first time to our knowledge a proxy for quality based on activity, i.e., on what deputies do, which is much more precise than what is usually used in the literature, e.g., absenteeism rate or years of schooling. We gathered from the Assemblée Nationale archive all the information that has been systematically collected over the years for each deputy and for each year from 1958 to 2012: (i) propositions of law, (ii) oral questions, (iii) reports and (iv) debates in which the deputy has been involved in. From these four aspects of parliamentary work, we compute a composite indicator of 
activity using an $\alpha$-domination estimator, based on Aragon et al. (2006) and Daraio and Simar (2007). As it is a fully nonparametric estimator, no arbitrary weights are imposed on the different activity items.

Second, we provide a counterfactual empirical study for the empirical work of Galasso and Nannicini (2011) by adopting a fully flexible nonparametric regression framework. Their theoretical framework does not impose a specific functional relation between the political competition and the quality of politicians, but rather stipulates properties of the relationship ${ }^{1}$ (i.e., electoral competition and politicians' quality are positively related). False imposition of a functional form in the empirical analysis can lead to biased estimates, which in turn can imply erroneous inference. The nonparametric framework that we adopt does not require any assumption about the relationship between electoral competition and the activity of deputies, which is of particular interest considering the richness of our original dataset. This implies that we allow for non-linearities and interactions with the many (discrete or continuous) control variables. In particular, we use a kernel localized least square regression proposed by Racine and Li (2004), which is general in the sense that a parametric OLS estimation is a special case of the applied approach ${ }^{2}$. As such, the interpretation of the results is analog to those obtained with parametric OLS. The main difference is that we estimate observation-specific gradients (i.e., the marginal effect evaluated at a specific percentile of the regressor's distribution) instead of sample-wide gradients ${ }^{3}$.

A third major innovation of our empirical analysis is that we fully exploit the large time span of our dataset to test whether the discussed relationship is time-varying. In France as in Europe, the progressive convergence of the competing political platforms over the second part of the $X X t h$ century, marked by the reconciliation of the left with the market in the early 80's, suggests that the electorate became more ideologically neutral, hence more sensitive to the quality of the candidates (Green, 2007; Knapp and Wright, 2001). We test whether the intensity of the competition/selection

\footnotetext{
${ }^{1}$ This is consistent with a survey of Yatchew (1998) indicating that micro-economic theory almost never dictates a specific functional form relating economic variables.

${ }^{2}$ See Li and Racine (2007) p. 83 for a discussion of the relation between parametric OLS and the applied local linear regression.

${ }^{3}$ See also Balaguer-Coll et al. (2007), Henderson et al. (2013) and Henderson and Parmeter (2015) for a discussion of the usefulness of the applied nonparametric econometric tools that deal with a mixture of continuous and discrete regressors.
} 
relationship increased (or not) over time. The nonparametric framework provides the warranted flexibility to reveal how the relationship between electoral competition and the quality of politicians evolved over the half-century covered by our sample. To our knowledge this is the first exploration of drivers of political selection over time.

Overall, our results point a clear positive relationship between electoral competition and political selection. Deputies elected in ex ante competitive districts exhibit a higher level of activity, ceteris paribus, which is not driven by reelection incentives. This relationship is robust to different specifications. The overall activity of deputies is continuously increasing over time, but the intensity of the relationship between competition and quality, after having increased till the early 80's, is continuously decreasing since then, and turns insignificant since the beginning of the 2000's. The political context of the 70's and 80's is the closest one to the theoretical hypothesis of the Galasso and Nannicini (2011) model, providing support to their formalization of the link between competition and selection.

The remaining of the paper is structured as follows. In section 2 we present the theoretical background. Section 3 briefly describes the French political and institutional context. We introduce our proxy for quality and of electoral competition together with the dataset in Section 4. Section 5 presents the nonparametric kernel approach. The results are detailed in Section 6, and Section 7 concludes.

\section{Theoretical framework}

While the link between competition in the political market and economic outcomes is well established (Besley et al., 2010; Besley and Preston, 2007; Padovano and Ricciuti, 2009; Solé-Ollé, 2006), the role of political competition is often left implicit; it is not always clear whether competition plays a disciplining role (incentivizing incumbents to adopt good policies) or helps selecting politicians of higher quality (who are better equipped to formulate good policies).

To our knowledge, only Galasso and Nannicini (2011) and De Paola and Scoppa (2011) exclusively focus on the impact of electoral competition on political selection, respectively in the context of the Italian Parliament and Italian municipalities. While De Paola and Scoppa (2011) show that mayors elected in contested municipalities 
are more educated, Galasso and Nannicini (2011) go one step further and show that deputies coming from highly competitive districts exert more effort, as measured by absenteeism rate, even after controlling for reelection incentives. They are the first to propose (and test) a formal model explicitly relating electoral competition to the quality of elected representatives and attribute a central role to political parties. At the opposite of the citizen candidate model (Besley and Coate, 1997; Osborne and Slivinski, 1996), this model focuses on the demand side of the political market, which is more suitable for democracies like France where political competition opposes parties $^{4}$.

To briefly sum-up the model, two ideological parties compete in a majoritarian system characterized by plurality rule in single-member districts. Each district is composed of a specific share of party supporters and neutral voters. The former always vote for their favorite party. The latter are uniformly distributed on a leftright spectrum (and thus are more or less close to a specific party). Neutral voters care about the national policy that the winning party will implement, but also about the quality of the elected incumbent in their district. Quality of politicians is assumed to be observable before the elections, by both voters and parties.

Parties can select two types of candidates: loyalists and experts, respectively of low and high quality. An important assumption is that recruiting high quality candidates is costly for parties, for example because of a higher financial compensation for their opportunity cost, or because of a minor dedication to party propaganda. To win the elections, a party needs to win more than $50 \%$ of the districts. The distribution of the three types of voters over the districts determines the ex ante contestability of each district (ex ante since parties base their strategy on this information, before the election). In some districts, the bias in favor of a party is so important that the outcome of the election is certain. In other districts, the parties need to attract votes of the neutral voters, who vote according to a standard probabilistic voting model.

In this set up, parties recruit the same proportion of experts, and allocate them to the most contested districts. This implies that high-quality candidates are confronted

\footnotetext{
${ }^{4}$ The importance of parties in the selection process has previously been emphasized (Carrillo and Mariotti, 2001; Caillaud and Tirole, 2002; Mattozzi and Merlo, 2010; Poutvaara and Takalo, 2007).
} 
to each other. Intuitively, the latter result comes from the fact that allocating an expert to an uncontested district is useless for both parties: the party benefiting of the bias has no interest in recruiting a costly expert since the victory is certain; the same applies for the other party since defeat is unavoidable.

The model shows the conditions for a positive relationship between electoral competition and political selection, which is the main hypothesis that we want to verify. In this framework, it is easy to verify that the magnitude of the relationship is time-varying as it is highly likely the institutional setting (including the party polarization and the share of neutral voters) is time-varying as well. Insight in the evolution of the relationship over time is important to understand the drivers of political selection, which is the other main concern of this paper. We carefully discuss the French institutional and political context to consider how the institutional setting fits this framework while being time-varying.

\section{The French institutional context}

With a powerful presidency and a prime minister subject to assembly confidence, the French $V^{\text {th }}$ Republic can be described as a semi-presidential system (Shugart, 2005). The Parliament is bicameral, consisting of the Sénat and the Assemblée Nationale. Contrary to senators, deputies of the National Assembly are elected by universal direct suffrage, explaining our focus on this chamber.

\subsection{The parliamentary work}

The legislative process starts when either the government or a MP introduces a bill in one of the two chambers. Once put on the agenda of the debates, it is first discussed in the relevant committee of the chamber where the bill is introduced. Each bill is granted a rapporteur, i.e., a deputy playing a key role by supervising the evolution of the bill. The bill and its amendments are then discussed and voted in a plenary session. If adopted, the bill then moves to the second chamber, where it is again discussed. If the second chamber adopts the text without any modification, the bill is then promulgated by the President of the Republic. If any modification is implemented by the second chamber, the bill goes back to the initial chamber, where 
it is discussed again. The bill travels across the two chambers until a common text is adopted. In case of persistant disagreement, a joint committee composed of seven deputies and seven senators is created (Commission Mixte Paritaire), with the aim to reach a consensus. The resulting text is then submitted to the two chambers. If the disagreement still persists, the constitution moreover gives the final word to the Assemblée Nationale.

The role of a deputy is threefold: to take part into the elaboration of the legislation, to control the government and to represent the electorate. To play a role in the elaboration of the legislation, a deputy can first propose a bill. If between $80 \%$ and $90 \%$ of the laws are initiated by the government ${ }^{5}$, proposing a bill is a part of the legislative process: bills initiated by the government are often based on previous bills proposed by deputies (Avril, 2005). Even bills proposed by opposition deputies, having a very low chance of turning into laws, can serve as a basis for future legislation in favor of a change of the majority at the upcoming election. For instance, the decentralization of the state and the tax on high personal wealth were both proposed by socialist deputies when the right-wing was in power, before being implemented after the election of François Mitterrand in 1981. This makes the distinction between bills originating from the government and bills originating from deputies rather fuzzy (Carcassonne, 1989).

Knapp and Wright (2001) notice that bills promoted by individual deputies are not confined to minor issues, for instance the repression of incitement to racial hatred (loi Gayssot, 1990) or the regulation of political parties fundings (loi Séguin, 1995). Another way for deputies to affect the legislative process is through amendments $^{6}$. The amendments are first discussed within committees, then during plenary sessions. During these plenary sessions, the author of amendment, the reporter of the law, a representative of the government and an orator against the amendment

\footnotetext{
${ }^{5}$ This number is computed on the overall legislative production, including ratification of treaties and approval of international agreement. As pointed by Avril (2005), the share of government bills decreases from $81 \%$ to $63 \%$ over the 1997-2002 period if we exclude those formal legislative acts. As a comparison, the parliamentarians' share of legislation in the British House of Commons is always under 10\% (Knapp and Wright, 2001).

${ }^{6}$ During the 2003-2004 parliamentary session, Avril (2005) reports than only 8 laws out of 40 have been promulgated without any modification. For the others, 4186 amendments have been adopted, including 2127 originating from committees, 874 from the UMP group (the political majority), 613 from the government, and 348 from the Socialists (opposition).
} 
can successively have the floor.

The second function of a deputy is to control the executive power. As the government is responsible before the National Assembly, it imposes de facto some limits to the government discretionary power, even if the chamber dismissed a government only once, in 1962. Questions are the most direct tool for deputies to control the government. Article 48 of the constitution also grants deputies with the right to ask oral questions to government members during specific plenary sessions. Political groups share the amount of time devoted to questions proportionally to their size. Then each political group, organized around a board and a secretary, selects the speaking deputies. Written questions are sent by an individual deputy to a minister, who has to answer within two months. The process of asking questions to the government can also be seen as a way to transmit information about constituencies' concerns, and as such represent the electorate, which is the third function of a deputy.

\subsection{The political context}

The institutional context described in Galasso and Nannicini (2011) model relies on three specific features. First, the electoral system is a two-round majoritarian system characterized by plurality rule in single-member districts. Second, two parties compete for these elections. Third, parties recruit and allocate their candidates strategically, depending on the contestability of the districts, implying a centralized selection process. We successively describe how the French context fits these three features, before focusing on the evolution of the context.

The deputies of the French National Assembly are elected with a two-round majoritarian system. The natural length of a legislature is five years, but the president of the Republic can dissolve the Assembly. There is no term limit. Each constituency elects one deputy. If no candidate receives more than $50 \%$ of the votes at the first round, only candidates obtaining more than $12.5 \%$ of the votes in the first round are qualified for the second round. In the vast majority of cases, only two candidates run for the second round. The only exception to these electoral rules is the 1986 elections, which adopted a proportional system ${ }^{7}$.

\footnotetext{
${ }^{7}$ The reason of this change is purely strategical. François Mitterrand, President since 1981, saw
} 
The party system can be described as 'bipolar multipartism' (Knapp and Wright, 2001; Knapp, 2002): in line with Duverger (1973), the two-round majoritarian electoral system is a force tending to bipolarisation, but each pole remains multiparty. The governing majority is based on a clear left-wing or right-wing coalition, and does not rely on a pivot party likely to change partner during a legislature, ensuring stability $^{8}$. In a general case, a deputy has to first compete against candidates of the same wing but from different parties in the first round, before confronting the opposite wing candidate at the second round. If this is not a pure two party competition, the mechanism is similar, especially in the $70 \mathrm{~s}$ and $80 \mathrm{~s}$ when the 'overall victory against the opposite camp became less important than regaining a dominant position against allies' (Knapp and Wright, 2001). A departure from this two bloc description is the progressive rise of the Front National, an extreme-right, populist party. The vote for this party is known to be essentially a vote of protest based on national considerations(Mayer and Perrineau, 1992). As such, it is reasonable to assume that supporters of this party do not consider candidates and their respective quality when they cast their vote. This implies that this third party has no interest in seeking the votes of the neutral citizens by selecting high profile candidates, and is not likely to substantially impact the allocating strategy of the other parties: the competition between the two other blocs in order to attract neutral voters remains virtually the same. Another aspect limiting the role of the Front National is its difficulty to recruit candidates. The party is often not able to present a candidate in every district: only 550 candidates ran for the party in the 2007 legislative elections, for a total of 577 seats.

Despite some differences among parties, the candidate selection process is overall highly centralized (Lundell, 20014; Thiébault, 1988). There is no law concerning candidate selection, as it is the case for instance in the United States. The basic organization is a central committee studying and eventually modifying propositions of the local base. The candidate is not necessary originating from the constituency. A 'parachutage' describes a situation in which a candidate is strategically sent to a constituency with which he/she does not have any previous link with. An illustrative

this electoral reform as a way to soften the anticipated upcoming defeat (Chevallier et al., 2012). The original design came back for the next elections, together with a major redistricting. Since then, the number of deputies kept stable at 577 .

${ }^{8}$ Centrist parties traditionally supported right-wing governments. 
example is the operation 'young wolves' in 1967. The Gaullist party allocated ten young and talented politicians from Paris (among them the future President Jacques Chirac) in constituencies located in the Center-West of France, dominated by the left-wing but winnable. The reaction of the main left-party was to allocate Roland Dumas, a prestigious lawyer, future Foreign Affairs Minister, and Robert Mitterrand, the brother of future president François Mitterrand. This example also provides an anecdotal evidence of the strategical use of candidate selection by parties as well as the convergence of candidates' quality in close races as expressed by the theoretical framework. More recent evidences of such a convergence could be the first election of François Hollande in 1988 against another énarque in a rural constituency, or the opposition in the 2012 elections between Jean-Luc Mélenchon, leader of a left-wing party and candidate for presidential election earlier the same year, and Marine Le Pen, leader of the extreme-right party and who also run for presidential election, while the Socialist party selected a university professor and the center-right another énarque.

Concerning the time-variation in institutional context, the most noticeable evolution over the second part of the $X X^{\text {th }}$ century in France is certainly the ideological convergence after the 80 's, marked with the reconciliation of the Socialist Party with the market and the rise of the Pensée unique (Knapp and Wright, 2001). According to the theoretical model of Galasso and Nannicini (2011), such an evolution should have decreased ideological voting and produced more competence-based elections (Green, 2007). The selection process of the parties should have been more thorough and careful, resulting in a tighter relationship between electoral competition and political selection.

A second factor that might have impacted the electoral competition/selection process relationship is the continuously increasing volatility of voters over time, i.e., an increasing unpredictability of their voting behavior. The effect of this well documented phenomenon (Drummond, 2006; Ysmal, 1994) is ambiguous. In light of the theoretical model, an increase of the volatility can be associated with an increase of the share of neutral voters. Hence this should enhance the effect of electoral competition on political selection. On the other hand, Knapp (2002) suggest that this might have had the opposite consequence. The increasing volatility leads the power to change hands at every national election between 1981 and 2002. Allocating can- 
didates may have become more difficult since the link between ex ante competition and effective competition is less straightforward.

Two other factors may have weakened the competition/selection mechanism. A common evolution of the candidate selection process of all parties is an expansion of their electorate, i.e., the selection process became progressively more collective (Hazan and Rahat, 2010). This collective decision making may be a source of inefficiency concerning the strategic allocation of candidates. Third, the party membership grew up till the early 80's and continuously decreased since then (Knapp, 2002). This implies a declining stock of potential candidates in which parties can recruit. Active partisanship is a way for parties to screen and identify promising politicians (Best and Cotta, 2000).

In sum, a priori it is not clear which were the main drivers of political selection and its relation with electoral competition. An empirical examination is needed to clarify the changing importance of the discussed relation.

\section{Data and measurement}

To study the relationship between political competition and political selection, we constructed a dataset which contains detailed individual information about all the members of the French National Assembly from its first effective working year in 1959 to the end of the $X I I I^{\text {th }}$ legislature in 2012 at a yearly rate. We keep only deputies who stayed in office the whole legislature (more than 2,400), for a total of over 24,000 observations.

\subsection{Proxying quality}

Proxying the quality of politicians is not straightforward. A wide theoretical acceptation is that quality is a combination of competence and motivation ${ }^{9}$ (Besley, 2006). Motivation and competence are valence issues, which means that voters agree that

\footnotetext{
${ }^{9}$ Motivation here is not driven by incentives, but can be related to what Bénabou and Tirole (2003) call 'intrinsic motivation', or Besley (2006) 'public spiritedness'. A third conventional component of quality is honesty, but to our knowledge, this concept has never been operationalized. See Besley (2006) for a discussion.
} 
a higher level of motivation and competence is desirable. Such a broad definition is challenging to operationalize. The existing empirical literature relies on two different strategies. The first strategy consists in using ex ante measures of quality, such as schooling and experience (Baltrunaite et al., 2014; Besley et al., 2011; De Paola and Scoppa, 2011; Kotakorpi and Poutvaara, 2011). The link with the theoretical definition of quality is however not direct as these proxies fail to capture the multidimensional definition of quality. The second strategy consists in measuring the quality of politicians ex post, according to their performance in office. But again, measuring the performance of an individual politician is not straightforward. Galasso and Nannicini (2011) use the absenteeism rate, while Gagliarducci and Nannicini (2013) use the vote attendance. These measures are however potentially weak proxies of a deputy's effective activity within the parliament: a deputy can be present but asleep, and a vote procedure only requires the push of a button or the raise of a hand.

We innovate by constructing a proxy for quality based on what a deputy actually does in the Parliament. To do so, we exploit the Tables Nominatives, a document edited by the National Assembly every legislature registering the individual activity of each deputy. It contains four items: (i) oral questions, (ii) debates in which the deputy has been significantly involved in, (iii) propositions of law ${ }^{10}$ and (iv) reports. Gathering this official information has the advantage of using information that the institution itself selected as relevant, independently of the choice of the analyst.

To be a relevant proxy for quality, the overall level of activity should be a (positive) function of both intrinsic motivation and competence. The link between overall activity and motivation is direct: a deputy never showing up in the chamber cannot have a significant recorded activity. The link between activity and competence comes from the inner organisation of the political groups within the Parliament. As explained in Section 3, each group is based on a secretary and a board. These organs regulate the activity of their members. It affects the four activity items that we gathered: a political group selects the list of its speakers in debates (for example to defend an amendment). The group also composes the list of orators for the sessions of questions to the government. If theoretically a deputy is free to propose a bill, the group nevertheless exerts to some extent a control and check for instance the

\footnotetext{
${ }^{10}$ In those Tables, only propositions of law for which the deputy is the main author are considered, and not all those that he/she cosigned.
} 
suitability of the bill with the political ideology. Finally, the selection of the reporter of a bill is based on a consensus between the president of the committee and the presidents of political groups. For these items, the level of expertise plays a crucial role in the distribution of the tasks (Carcassonne, 1993). It is thus necessary for a deputy to demonstrate the quality of his/her work to play an effective role (Davin, 1985; Thiébault and Dolez, 1988). So even if we do not have any information about the quality of the individual work ${ }^{11}$ (e.g., we do not observe whether an intervention in the debate helped the point further), this gatekeeping mechanism prevents hyperactive but inconsequential deputies to monopolize the floor, implying a link between activity and competence. We thus posit that quality is positively and strongly correlated with the overall level of activity ${ }^{12}$.

In this paper, we fully acknowledge deputies as agents that use their inputs to produce the multiple aspects of parliamentary activity. Using each activity item as an endogenous variable successively would be inappropriate, as it would exclude the possibility of specialization. Some deputies might be specialist of report writing, while for instance some others might be excellent in rhetoric and thus used by their political groups exclusively in the debates. Table 1 shows the correlation between the different items and confirms the specialization hypothesis. We find that $65 \%$ of deputies have shown no activity in at least one aspect and $20 \%$ fully specialize in one aspect of parliamentary work. In addition, we gathered attendance rate of deputies ${ }^{13}$, which is only available for the $X I I I^{\text {th }}$ legislature, and compute the correlation coefficient with activity items of deputies belonging to this legislature. Table 1 also shows that the correlation between activity and attendance rate is rather low, confirming the need to use a quality proxy which is more complex than attendance.

\footnotetext{
${ }^{11}$ We are not able to evaluate individually each individual act, not only for practical reasons (the number of acts to evaluate) but also because of a lack of normative criteria.

${ }^{12}$ Disentangling competence from effort, beside conceptual and technical difficulties, is beyond the scope of this paper.

${ }^{13}$ Attendance is measured by the number of week of attendance per year. This information is provided by the watchdog website www.nosdeputes.fr. There is no information about voting attendance, since deputies can vote in the name of their colleagues for most of the votes.
} 
Table 1: Correlation of activity items

\begin{tabular}{rrrrrr}
\hline & Attendance & Reports & Questions & Interventions & Propositions \\
\hline Attendance & 1 & & & & \\
Reports & 0.350 & 1 & & & \\
Questions & 0.346 & 0.062 & 1 & & 1 \\
Interventions & 0.593 & 0.290 & 0.447 & 0.267 & \\
Propositions & 0.140 & 0.077 & 0.221 & & \\
\hline
\end{tabular}

One could simply use a weighted sum, but such weights would however be subjective, and the literature about the French parliament does not provide any information about this. An alternative for imposing a priori defined weights is the use of a nonparametric composite indicator that allows for an endogenous weighting of the different outputs via linear programming, such as DEA or FDH. The model grants each deputy its most favorable weights and thus allows for full specialization. However, the important number of extreme values in our data precludes the use of these frontier methods ${ }^{14}$. These nonparametric efficiency methods are based on the computation of the boundary of the attainable set (the so called efficiency frontier), which is highly sensible to outliers (Cazals et al., 2002).

To avoid this problem we use an alternative probability-based score to measure the multidimensional parliamentary activity: the $\alpha$-efficiency estimator of Aragon et al. (2006) and Daraio and Simar $(2007)^{15}$. Particularly convenient is that a) this indicator is robust to outlying observations, b) it is consistent with production theory and c) it is easy to interpret. The $\alpha$-performance is defined for observation $i$ with $d$-dimensional output $y_{i}=\left(y_{i 1}, \ldots, y_{i d}\right)$ and $k$-dimensional input $x_{i}=\left(x_{i 1}, \ldots, x_{i k}\right)$ as the probability that another observation does not produce more of each output using a level of input less or equal to $x$, with $\alpha_{i}\left(y_{i}, x_{i}\right) \in[0,1]$, higher values indicating higher activity:

$$
\alpha_{i}\left(y_{i}, x_{i}\right)=1-S_{Y \mid X}, \text { with } S_{Y \mid X}=\operatorname{Prob}\left(y \geq y_{i} \mid x \leq x_{i}\right) .
$$

Stated differently, the $\alpha$-measure provides the probability for a deputy not to be

\footnotetext{
${ }^{14}$ See Fried et al. (2008) for an extensive overview.

${ }^{15}$ See e.g. Tulkens (2006) for a discussion of domination-based indicators.
} 
dominated by another deputy taken randomly. The concept of dominance here is similar to the one extensively used in game theory. The vector $y$ is composed of our four outputs of parliamentary activity.

Concerning input vector $x$, we normalize the input to 1 for all deputies for three reasons. First, we consider that all deputies have the same tools (e.g., the same grant for hiring staff) and twenty-four hours per day. As such, we follow the principle of Carcassonne (1993): '[...] all parliamentarians are equal in rights. It depends only on themselves to seize opportunities they face. Talent will then determine successful attempts, and this is not the least legitimate principle'. A second motivation for this choice is the lack of adequate data on the inputs of deputies. For instance, we do not know how a deputy shares his/her time among the different activities. Our analysis is general in the sense that if such detailed information would exist, we could easily include this information into the analysis (see Cherchye et al., 2013 and Cherchye et al., 2014). Third, we consider a deputy as a helmsman steering his office (see Koopmans, 1951 and Cherchye et al., 2007 for a discussion of the helmsman interpretation in a macro-performance setting). This interpretation is convenient, as we are interested in the multi-dimensional activity the deputy provides and not in how well the deputy organises his/her work. Also, ex ante measures such as schooling are not considered as inputs. Doing so would a priori imply that we provide some excuse to low educated deputies to underperform ${ }^{16}$. Further, as we discuss in section 6 , schooling is only associated with higher activity for low levels of schooling, making any conditioning on schooling unwanted for higher levels of schooling. Last, conditioning on schooling would make the comparison among the whole set of deputies less clear. We thus prefer to compute an unconditional measure of performance and to control for education in the second step, as we shall see in the next section.

The empirical estimation of the $\alpha$-domination measure for deputy $i$ is obtained by computing:

\footnotetext{
${ }^{16}$ For instance, if a low educated deputy produces, say, 1 proposition, while all the other deputies with the same level of education produce 0 , this deputy would be considered more productive than a highly educated deputy producing the average output of the deputies with the same level of education.
} 


$$
\hat{\alpha}_{i}\left(y, y_{i}\right)=1-\hat{S}_{y, y_{i}}=1-\frac{\sum_{j=1} I\left(y_{j} \geq y_{i}\right)}{n},
$$

with $n$ the total number of individuals, $y_{i}$ and $y_{j}$ the multidimensional output of respectively deputy $i$ and $j, I$ the indicator function, taking the value 1 if $y_{j} \geq y_{i}$ is true, 0 otherwise. To illustrate the functioning of the measure, consider a deputy $i$ producing $\left(y_{i 1}, y_{i 2}, y_{i 3}, y_{i 4}\right)=(2,2,2,2)$, with $y_{i 1}, y_{i 2}, y_{i 3}$ and $y_{i 4}$ respectively denoting reports, questions, propositions of law and debates. This deputy is dominated by a second deputy producing $(3,2,2,2)$, and dominates a third deputy producing $(2,1,2,2)$. Furthermore, compared to a fourth deputy producing $(3,0,0,0)$, the production of each deputy does not dominate the other. By applying the methodology, we obtain a full ranking of deputies according to their overall parliamentary activity without imposing any weight to the different items composing their work and allowing for full specialization ${ }^{17}$. Descriptive statistics of this measure are provided in Table 3.

\subsection{Measuring political competition}

Various measures of political competition have been used in the literature, from the number of parties competing for an election (Ashworth et al., 2014) to the length a party stayed in office (Skilling and Zeckhauser, 2002). The most commonly used measure is based on the vote-margin, computed between the vote share of the winner and the runner-up (for instance Becker et al. (2009); De Paola and Scoppa (2011); Padovano and Ricciuti (2009)) or between the vote share of the winner and $50 \%$ (Solé-Ollé and Viladecans-Marsal, 2012). Given the two-round system of the French set up, a possibility could be to use the vote-margin at the decisive round. This might however be spurious because the decisive round is not everywhere the same, some deputies winning the elections at the first round. Using only jurisdictions where elections needed two rounds would considerably reduce the number of observations available, and the voter transference occurring between the two rounds could depict a spurious degree of contestability. An illustrative example is the presidential election of 2002, which exhibits a very similar electoral system. At the first round, Jacques

\footnotetext{
${ }^{17}$ Anecdotally, Charles de Courson and Gilles Carrez, two deputies dominating the rankings established by newspapers in recent years, appear in the top $1 \%$ of our ranking.
} 
Chirac obtained only $20 \%$ of the votes, while the runner-up, the extreme-right leader Jean-Marie Le Pen, received 17\%. Both have been qualified for the second round, and Lionel Jospin, the candidate of the Socialist Party, has been eliminated with $16 \%$ of the votes. At the second round, Jacques Chirac won with the dictator-like score of $82 \%$ of the votes. The vote margin at the second round would indicate a very low degree of competition. Looking at the first-round score, with three candidates in 4 percentage points, this is obviously not the case. Our favorite measure of political competition $C$ is based on a Herfindahl index based on the first round, as for instance in Larcinese (2014) and De Paola and Scoppa (2011) ${ }^{18}$. It is computed as follows:

$$
C=1-\sum_{i=1} s_{i}^{2}
$$

where $s_{i}$ is the vote share at the first round obtained by party $i$. We compute this measure for each constituency and for each election, using data provided by the Ministry of Interior. To ensure that a Herfindahl-based measure captures the real degree of electoral competition, we compute for each constituency dif $=C_{t}-C_{t-1}$, which measures the evolution of the district competitiveness over time and report it in Figure 1. The black dots indicate the average value of dif. An average above 0 indicates an increase of electoral competition, while an average below 0 indicates a decrease. The picture is consistent with the political history. For instance, the same parties were competing in 1958 and 1962, resulting in a stagnation of competition; the 1967 elections ( $I I^{r d}$ legislature) mark the decline of the bias in favor of Gaullism, which continued in the 1968 elections, opening the elections. The drop observed between the $I V^{t h}$ and the $V^{t h}$ is due to the union and electoral agreement of the Communist and Socialist parties. More recently, the overall increase of competition by the end of the period can be explained by the refusal of the Ecologist Party to renew their agreement with the Socialists in 2002 and the rise of the extreme-right party.

\footnotetext{
${ }^{18}$ Note that this measure is correlated with the vote-margins at both the first and the second round, with a correlation coefficient of respectively -0.499 and -0.231 . The three alternative measures hence describe a similar situation.
} 
Figure 1: Herfindhal index over legislatures

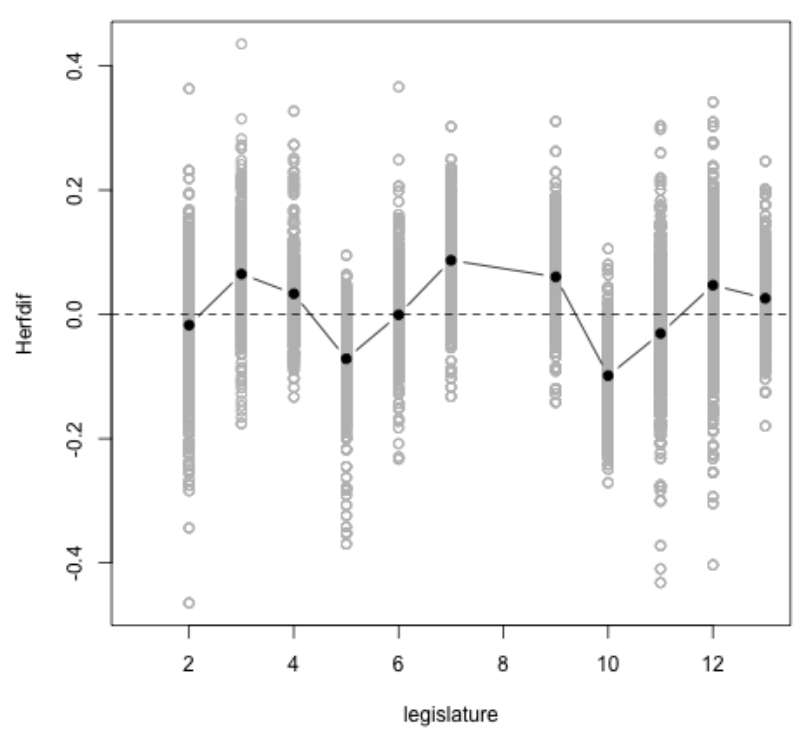

Table 2: Probability to Swing

\begin{tabular}{rr}
\hline Endogenous : & Swing \\
\hline Competition & $\begin{array}{r}1.270^{* * *} \\
(0.182) \\
\text { Intercept } \\
-1.302^{* * *} \\
(0.251)\end{array}$ \\
\hline Model & Probit \\
Observations & 4151 \\
\hline${ }^{*} p<0.05,{ }^{* *} p<0.01,{ }^{* * *} p<0.001$
\end{tabular}

The theoretical framework provided by Galasso and Nannicini (2011) implies that electoral competition should be measured ex ante: parties use this information prior to elections to recruit and allocate their candidates. Competition for elections at time $t$ is consequently measured by the Herfindahl index at the previous elections. Because of the change in the voting rules for the 1988 elections, we do not have ex ante measure of competition for this legislature. The same applies for the first legislature. 
We also excluded a few constituencies when their borders changed from one election to another. To verify the validity of this ex ante measure of competition, we estimate its impact on the probability that a constituency swings. To do so, we estimate a probit model with a dummy indicating whether the majority changed as endogenous variable and our measure of political competition as explanatory variable. Results are provided in Table 2, and clearly show that the higher the ex ante competition, the higher the probability for a constituency to swing. 
Table 3: Descriptive statistics

\begin{tabular}{|c|c|c|c|c|}
\hline & N. Observations & Mean & Min & $\operatorname{Max}$ \\
\hline Propositions & 24011 & 0.602 & 0 & 34 \\
\hline Questions & 24011 & 1.154 & 0 & 29 \\
\hline Reports & 24011 & 0.681 & 0 & 30 \\
\hline Debates & 24011 & 3.243 & 0 & 53 \\
\hline Activity & 24011 & 0.671 & 0.000 & 1.000 \\
\hline Competition & 20868 & 0.724 & 0.206 & 0.945 \\
\hline Left & 24011 & 0.375 & 0 & 1 \\
\hline Right & 24011 & 0.549 & 0 & 1 \\
\hline Center & 24011 & 0.075 & 0 & 1 \\
\hline Majority & 24011 & 0.610 & 0 & 1 \\
\hline Group size & 24011 & 178.5 & 0 & 363 \\
\hline Experience & 24011 & 7.798 & 1 & 45 \\
\hline Mayor & 24011 & 0.511 & 1 & 0 \\
\hline Women & 24011 & 0.059 & 0 & 1 \\
\hline Age & 24011 & 53.92 & 26 & 93 \\
\hline Schooling & 24011 & 15.36 & 5 & 21 \\
\hline ENA & 24011 & 0.044 & 0 & 1 \\
\hline Teaching & 24011 & 0.151 & 0 & 1 \\
\hline Healthcare & 24011 & 0.119 & 0 & 1 \\
\hline Legal & 24011 & 0.091 & 0 & 1 \\
\hline Business & 24011 & 0.076 & 0 & 1 \\
\hline Academic & 24011 & 0.056 & 0 & 1 \\
\hline Farming & 24011 & 0.052 & 0 & 1 \\
\hline Politics & 24011 & 0.046 & 0 & 1 \\
\hline Engineering & 24011 & 0.041 & 0 & 1 \\
\hline Blue collar & 24011 & 0.034 & 0 & 1 \\
\hline
\end{tabular}




\subsection{Control variables}

The dataset contains several variables that are likely to impact the parliamentary activity of a deputy along with electoral competition. For each deputy, two sets of information are collected. The first set encompasses political variables. The political membership of a deputy is introduced through a variable indicating the political wing (Right, Center and Left), based on the political group to which the deputy belongs. We choose this categorization instead of focusing on individual parties to ensure a continuity over the 53 years of the sample. We also control whether the deputy is in the majority, and the number of deputies composing the political group. Several papers relate the size of a political group to free-riding behavior of its members (for instance Crain and Tollison, 1982 and Rogers, 2002). The committee of which the deputy is a member might also be important, as the agenda may give much more importance to some issues according to the period, impacting the amount of potential work of the deputies differently among the committees. The experience of deputies in the Parliament, measured in years, is included as well. All this information has been gathered from the Assemblée Nationale website ${ }^{19}$.

The second set focuses on personal variables. It encompasses civil status information, age and gender, but also occupation before the mandate and simultaneous mayoral mandate. We consider nine categories of occupation covering more than $65 \%$ of the deputies: teaching, healthcare, legal, business, academic, farming, politics, engineering and blue collars (industry workers). The dataset also contains the number of years of schooling, computed as the difference between the required number of years to receive the highest diploma obtained by a deputy and six, the age for mandatory school. In addition, a dummy variable indicates whether a deputy is a graduate of $E N A$, the prestigious high administration school from which many French politicians and administrators are graduated. Finally, there is an important debate in France about multiple-office holding and the possibility (or not) to correctly carry out parliamentary duties. A majority of deputies also has local government mandates, especially mayoral responsibilities. We introduce a variable indicating whether the deputy is simultaneously a mayor. This individual personal information comes from various sources: the National Assembly website and archive service, Who's Who

\footnotetext{
${ }^{19}$ www.assemblee-nationale.fr.
} 
in France dictionaries, several issues of the Jean Maitron's Dictionnaire Biographique du Mouvement Ouvrier Français, press articles, campaign leaflets, deputies' websites, biographies and memoirs (see Gavoille, 2014 for more details).

\section{Nonparametric regression approach}

The empirical model for deputy observations $i=1, \ldots, n$ is defined by a $n \times 1$ dependent scalar $\alpha$ (or $\hat{\alpha}$, our measure of activity), a $n \times v$ multivariate regressor $x=\left(x_{1}, \ldots, x_{v}\right)$ (encompassing our measure of political competition and control variables) and an additive error $\epsilon$ :

$$
\alpha_{i}=g\left(x_{i}\right)+\epsilon_{i}, \text { with } i=1, \ldots, n \text {. }
$$

This model can be estimated by imposing a parametric form, such as:

$$
\alpha_{i}=\beta_{0}+\beta_{1} x_{i 1}+\ldots+\beta_{q} x_{i v}+\epsilon_{i}, \text { with } i=1, \ldots, n \text {. }
$$

The problem with this specification is that, if there are non-linearities or interactions in the true model which are not parametrized, the empirical model is misspecified and the estimated coefficients are inconsistent (Henderson and Kumbhakar, 2006). Only little is known about the functional form linking electoral competition to quality, which is here proxied by activity. In order to avoid to impose a priori a functional relationship between the activity of deputies and electoral competition and hence to stay on the safe side, we implement a nonparametric approach ${ }^{20}$. Such an approach is especially relevant here considering the large size of our sample, as it lets 'the data speak freely'. A minimum of structure is therefore imposed, as a data-driven methodology directly chooses the shape of functional form linking activity to the covariates. There is thus nothing constraining the points to lie along a straight line, or along a low-order polynomial (Deaton, 1989). This in fact means that the effect of electoral competition on political competition is allowed to differ according to the level of electoral competition, but also that electoral competition is allowed to freely interact with the other covariates, e.g. legislature or year effects. The results are thus displayed in a graphical way, showing the impact of a covariate on the dependent

\footnotetext{
${ }^{20} \mathrm{See} \mathrm{Li}$ and Racine (2007) for an extensive overview of the used kernel regression approach
} 
variable for the different values taken by this covariate.

The main idea of a nonparametric (generalized) kernel regression is to approximate $E\left[\alpha_{i} \mid x=x_{i}\right]$ by means of $\hat{g}\left(x_{i}\right)=E\left[\alpha_{i} \mid \mathrm{x}\right.$ close to $\left.x_{i}\right]$, which implies localization in the direction of $x$. Following the nonparametric literature, $x_{i k}-x_{k}$ represents the distance between the level of regressor $k$ of deputy $i\left(x_{i k}\right)$ and all the observed levels of regressor $k\left(x_{k}\right)$. Bandwidth sizes determine which observations are 'close' in terms of $x$ and thus impose the window of localization. A kernel function is a weighting function giving more weight to observations near the observation point. Kernel functions are often chosen to be well-known density functions, but the choice of the kernel function has been shown to be of little importance ( $\mathrm{Li}$ and Racine, 2007). The choice of the kernel function depends on the nature of the variable, i.e., continuous, unordered and ordered. We use kernel weights $\left(l^{c}, l^{u}, l^{o}\right)$ with window widths $\left(\lambda^{c}, \lambda^{u}, \lambda^{o}\right)$ to specify the weight function for $x=\left[x^{c}, x^{u}, x^{o}\right]$, where $x^{c}$ is a vector of continuous values, $x^{u}$ is a vector of unordered discrete values and $x^{o}$ is a vector of ordered discrete values. In particular, we specify a gaussian kernel function $l^{c}$ to weight the continuous variable $x_{k}^{c}$ (see (5)). An Aitchison and Aitken (1976) kernel $l^{u}$ is specified to weight discrete unordered variable $x_{l}^{u}$ with $c_{l}$ categories and $\lambda_{l}^{u} \in\left[0,\left(c_{l}-1\right) / c_{l}\right]$ (see (6)). To weight the ordered discrete value $x_{m}^{o}$, we use a Wang and van Ryzin (1981) kernel function with $\lambda_{m}^{o} \in[0,1]$ (see (7)). ${ }^{21}$

$$
\begin{gathered}
l^{c}\left(\frac{x_{i k}^{c}-x_{k}^{c}}{\lambda_{k}^{c}}\right)=\frac{1}{\sqrt{2 \pi}} e^{-\frac{1}{2}\left(\frac{x_{i k}^{c}-x_{k}^{c}}{\lambda_{k}^{c}}\right)^{2}} . \\
l^{u}\left(x_{i l}^{u}, x_{l}^{u}, \lambda_{l}^{u}\right)=\left\{\begin{array}{l}
1-\lambda_{l}^{u} \text { if } x_{i l}^{u}=x_{l}^{u}, \\
\lambda_{l}^{u} /\left(c_{l}-1\right) \text { otherwise. }
\end{array}\right. \\
l^{o}\left(x_{i m}^{o}, x_{m}^{o}, \lambda_{m}^{o}\right)=\left\{\begin{array}{l}
1 \text { if } x_{i m}^{o}=x_{m}^{o}, \\
\left(\lambda_{m}^{o}\right)^{\left|x_{i m}^{o}-x_{m}^{o}\right|} \text { otherwise. }
\end{array}\right.
\end{gathered}
$$

To allow for a multivariate regression, we use product kernels (as is common practice). The product kernel of $x^{c}$ is $W_{\lambda^{c}}\left(x_{i}^{c}, x^{c}\right)=\prod_{k=1}^{q}\left(\lambda_{k}^{c}\right)^{-1} l^{c}\left(\left(x_{i k}^{c}-x_{k}^{c}\right) / \lambda_{k}^{c}\right)$. For $x^{u}$, the product kernel is defined as $L_{\lambda^{u}}\left(x_{i}^{u}, x^{u}\right)=\prod_{l=1}^{r} l^{u}\left(x_{i l}^{u}, x_{l}^{u}, \lambda_{l}^{u}\right)$. The product

\footnotetext{
${ }^{21}$ We estimated our model in R, making use of the "np package of Hayfield and Racine (2008).
} 
kernel of $x^{o}$ is $L_{\lambda^{o}}\left(x_{i}^{o}, x^{o}\right)=\prod_{m=1}^{s} l^{o}\left(x_{i m}^{o}, x_{m}^{o}, \lambda_{m}^{o}\right)$. All together, we can specify a Racine and $\mathrm{Li}$ (2004) generalized kernel function as:

$$
\mathcal{K}_{\gamma}\left(x_{i}, x\right)=W_{\lambda^{c}}\left(x_{i}^{c}, x^{c}\right) L_{\lambda^{u}}\left(x_{i}^{u}, x^{u}\right) L_{\lambda^{o}}\left(x_{i}^{o}, x^{o}\right), \text { with } \gamma=\left(\lambda^{c}, \lambda^{u}, \lambda^{o}\right)
$$

As discussed above, the choice of multivariate bandwidth $\gamma$ is of crucial importance. On the one hand, a too large bandwidth will produce biased estimates, because it will encompass observations that are far from $x_{i}$ and consequently less informative about $g\left(x_{i}\right)$. On the other hand, reducing the bandwidth leads to an increase in the variance of the estimates, because the number of observations considered in the neighborhood of $x_{i}$ decreases. There is thus a trade-off between bias and variance (Li and Racine, 2007). To select the bandwidth, we opt for an often used data-driven approach: the least-squares cross-validation $\operatorname{approach}^{22}$ (Li and Racine, 2004). It consists in finding the optimal bandwidth by minimizing the asymptotic integrated mean squared error (AIMSE). The least-squares cross-validation thus provides optimal bandwidth based on the minimization of:

$$
C V(\gamma)=\frac{1}{n} \sum_{i=1}^{n}\left(\alpha_{i}-\hat{g}_{-i}\left(x_{i}\right)\right)^{2} t\left(x_{i}\right) .
$$

where $\hat{g}_{-i}$ is the leave-one-out local-linear kernel estimator of $E\left(\alpha_{i} \mid x_{i}\right)$, and $0 \leq t(\cdot) \leq$ 1 is a weight function that serves to avoid difficulties caused by dividing by 0 or by the slower convergence rate arising when $x_{i}$ lies near the boundary of the support of $x$.

For the purpose of this study, we use a local linear regression which comes down to locally fitting a line - or a linear model if $x$ is multidimensional-for each observation using the observations within the interval determined by the bandwidth, given the kernel weights. In other words, we fit a local linear model through the observations in the neighborhood of observed levels $x_{i}$. If the window is large (i.e., very large bandwidth size), the curve will be a smooth straight line and we return to the linear least squares estimator without localization ${ }^{23}$. The least squares estimator can thus be seen as a special case of the local-linear estimator ( $\mathrm{Li}$ and Racine, 2007). If

\footnotetext{
${ }^{22}$ We opt for this approach over the AIC CV approach as the least-squares CV approach is more used in the literature and is faster to compute.

${ }^{23}$ This explains why the bandwidth is sometimes called the 'smoothing parameter'.
} 
the bandwidth is small, non-linearities are allowed for and the curve becomes less smooth. We opt for a local-linear estimator because the local-linear regression has better boundary properties than the local-constant regression (Hall et al., 2007).

The local-linear estimator estimates a local linear relation for each observation point $x_{i}$ by obtaining $a$ and $b$ in Equation (10):

$$
\min _{\{a, b\}} \sum_{i=1}^{n}\left(\alpha_{i}-a-\left(x_{i}-x\right)^{\prime} b\right)^{2} \mathcal{K}_{\gamma}\left(x_{i}, x\right) .
$$

Note that this equation describes a weighted least squares regression of $\alpha_{i}$ on $\left(x_{i}-x\right)$ with weights $\mathcal{K}_{\gamma}\left(x_{i}, x\right)$. That is, the estimator runs for each $x_{i}$ a regression with weights that are smaller for observations that are far from $x_{i}$. We use $x_{i}-x$ rather than $x_{i}$ as regressors in order to define the intercept $a_{i}$ as $g\left(x_{i}\right)=E\left[\alpha_{i} \mid x_{i}=x\right]$. That is, $\hat{g}\left(x_{i}\right)$ is the observation-specific constant term of the regression equation.

\section{$6 \quad$ Regression results}

\subsection{Base model}

The base model uses our measure of activity, which is discussed in detail in section 4.1, as the endogenous variable, and includes as explanatory variables the measure of electoral competition, the set of political variables (experience, mayor, committee, group size, majority and the political wing right, center and left) and the set of personal variables (age, gender, occupation, schooling and ENA). We introduce an ordered discrete variable representing the successive legislatures to take into account the political context and the evolution of time. The model also includes an unordered discrete variable to capture potential regional disparities as well as another variable indicating the first year of a legislature, since these years are not complete working years. We show the robustness of our results in Appendix. In particular, in Appendix A, we show that the results are robust for changing the ordered variable 'legislature' to the ordered variable 'year'. In Appendix B, we show that our main results are robust for altering the estimation methodology to parametric OLS.

We provide in Figure 2 the nonparametric results concerning the effect of elec- 
toral competition by showing the estimated level of activity (bounded between 0 and 1) as a function of the degree of competition, holding the other regressors equal to, respectively, the median for continuous variables and modus for discrete variables, using the $V I^{\text {th }}$ legislature (the median one) as the reference legislature. The dotted lines represent the $95 \%$ bootstrap confidence intervals. First of all, electoral competition does have a positive effect on activity, in accordance with the theoretical prediction of Galasso and Nannicini (2011): the tighter the ex ante competition, the more productive the elected official will be. Everything else equal, a deputy elected in the ex ante most contested district is estimated to reach a level of activity close to 0.8 , while if she is elected in a safe district her activity is estimated to be at most 0.6. This means that the activity of deputies can vary by up to $30 \%$ depending on the degree of contestability. The relationship is found to be linear. It suggests that there is no threshold above which electoral competition becomes harmful for political selection. This result is confirmed if we replace the legislature variables by year effects, as shown in Appendix A. The parametric model also indicates a positive relationship between competition and activity (see Appendix B). An alternative explanation of this relationship could be that parties may give deputies elected in contested districts more visibility by favoring their activity, say, by letting them be the first signatory of a joint initiative. This would imply that deputy facing an increased contestability in the upcoming elections should have a higher activity, especially before the elections. As we shall see in Section 6.3, we do not observe this phenomenon ${ }^{24}$.

As shown in the lower part of Figure 2, the general activity increased over the legislatures, suggesting an increase of the quality of deputies over time. An alternative explanation of this increase in activity might be an increase of the amount of laws produced by the Parliament. Since the government controls the agenda (see Padovano and Gavoille, 2014), if the government imposes an increased number of bills on the agenda, deputies might automatically have a higher activity. We document in Figure 3 that the average number of the total number of laws enacted each year only slightly increases over time. The increasing pace of EU directives can hardly explain much of the increase in the French legislative output. Most of the directives

\footnotetext{
${ }^{24}$ Anecdotally, the level of competition where Jean-Louis Gayssot and Michel Séguin, who initiated the two important pieces of legislation named after them mentioned in Section 3.1, had a level of competition respectively equal to 0.72 and 0.6 , so lower or equal than the mean level of competition.
} 
are transposed by decrees, which are enacted by the government. Brouard et al. (2012) document that between 1992 and 2004, only less than 10\% of EU directives were transposed by a law. Moreover, half of these laws are ratification of international treaties, which often follow a simplified procedure with only a debate within the committee and no discussion in plenary session, hence not affecting our measure of activity. In parallel, the panel b) of this figure shows that the share of 'ghost' deputies, i.e. deputies who do not have any recorded activity, reduced by $75 \%$ in fifty years. To observe the evolution of parliamentary activities more precisely, Figure 4 depicts the average of each activity item per deputy per year over the thirteen legislatures. The highest increase is observed for the average number of questions, which has been multiplied by more than three. The rise of this item, admittedly the most communication oriented item, boosts the increase of activity over years that we observe. But the three other items exhibit a positive trend too, evidencing that it is not the multiplication of questions that solely explains the increase in activity. 
Figure 2: Baseline model results

\section{Effect of Competition}

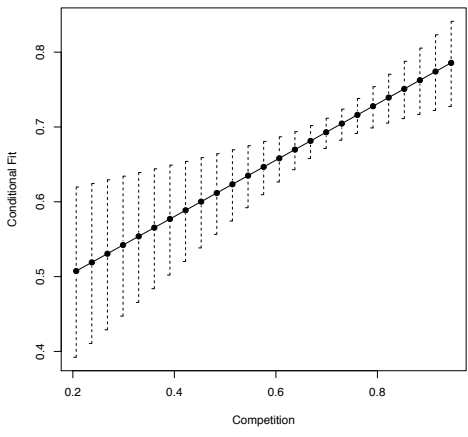

(a) Full sample

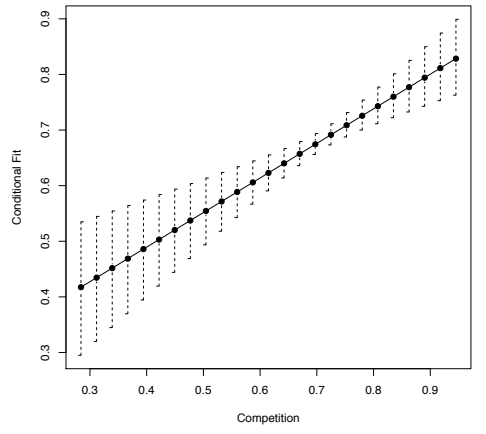

(b) Freshmen sample

Conditional activity over legislatures

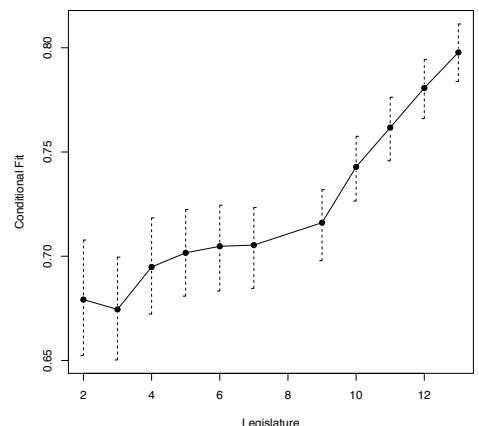

(c) Full sample

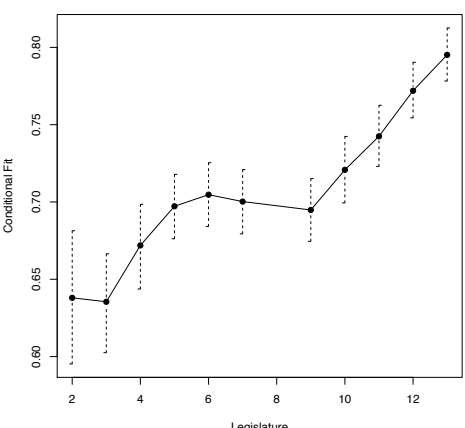

(d) Freshmen sample 
Figure 3: Legislative production and ghosts deputies

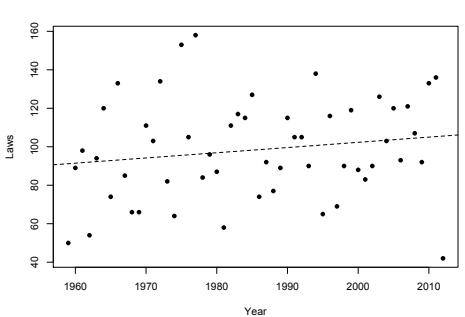

(a) Legislative production

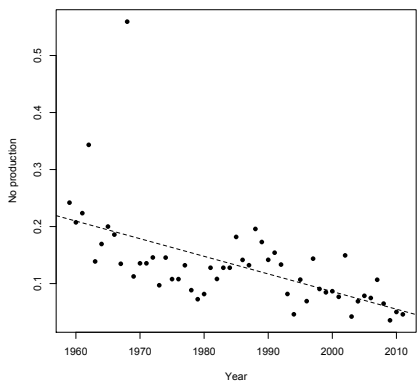

(b) Share of deputies who did not produce anything

Figure 4: Evolution of activity

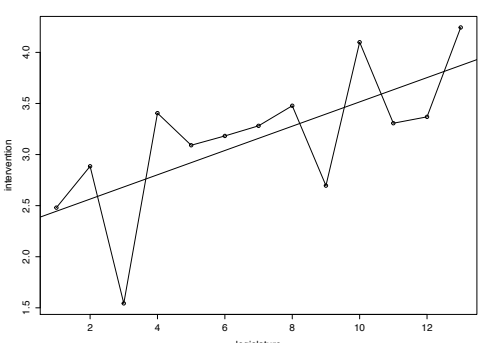

(a) Intervention

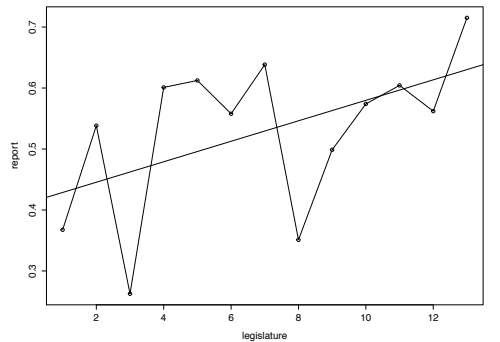

(c) Report

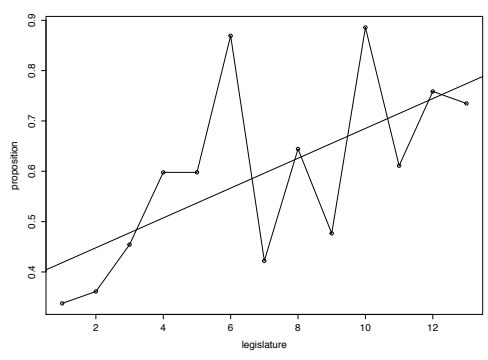

(b) Proposition

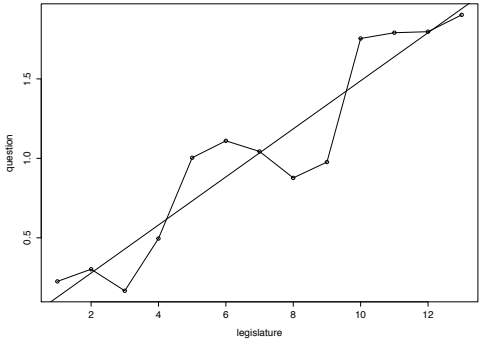

(d) Question

We present the results of the other explanatory variables in Table 4. For continuous variables, we report the marginal effect at the median, the minimum the second and third quartile and the maximum value. For categorical variables, we report the 
conditional fit according to the value taken by the variable. Values in brackets are the $95 \%$ confidence intervals. In addition, we also provide the R-squared statistic, which has the same interpretation as in the parametric framework. It shows the goodness-of-fit of the model.

In line with Besley et al. (2011), who show that more educated leaders are associated with better economic outcome, we find that schooling is positively correlated with our measure of quality. But the effect of an additional year of schooling is only important for low levels of schooling. There is also an interesting non-linearity in the impact of age: if one additional year does not significantly impact deputies' activity for young deputies, the impact becomes significant starting with the median age, and an extra year has an increasing negative impact on activity. The impact of experience on activity is negative and not linear ${ }^{25}$ : a marginal year of experience only matters for intermediate levels of experience. Finally, we do not find that group size exerts any effect on activity, contrary to the free-riding in legislature hypothesis.

Concerning categorical variables, results suggest that deputies who are simultaneously mayors tend to have a lower level of activity, even if this is not a significant effect. This result is consistent with Bach (2011), who fails to establish a causal impact of multiple office-holding on parliamentary activity. The three following variables, i.e. ENA, Majority and Woman, do not turn significant either. Similarly, we cannot say that deputies of a specific political group group tend to be more productive than others.

\footnotetext{
${ }^{25}$ The correlation coefficient between age and experience is mild (0.49).
} 
Table 4: Control variables - Full sample

\begin{tabular}{|c|c|c|c|c|c|}
\hline & Median & Min. & $25 \%$ & $75 \%$ & Max. \\
\hline \multicolumn{6}{|c|}{ Gradients of continuous variables } \\
\hline \multirow[t]{2}{*}{ Schooling } & $3.266^{*}$ & $16.534^{*}$ & -1.49 & 0.828 & 0.568 \\
\hline & {$[1.303,5.369]$} & {$[13.739,20.352]$} & {$[-5.436,2.513]$} & {$[-0.003,1.669]$} & {$[-0.867,2.24]$} \\
\hline \multirow[t]{2}{*}{ Age } & $-0.383^{*}$ & 0.093 & -0.003 & $-0.977^{*}$ & $-1.378^{*}$ \\
\hline & {$[-0.583,-0.19]$} & {$[-0.174,0.332]$} & {$[-0.169,0.151]$} & {$[-1.372,-0.592]$} & {$[-1.98,-0.787]$} \\
\hline \multirow[t]{2}{*}{ Experience } & $-0.391^{*}$ & -0.126 & $-0.295^{*}$ & $-0.389^{*}$ & -0.301 \\
\hline & {$[-0.712,-0.09]$} & {$[-0.4,0.119]$} & {$[-0.59,-0.028]$} & {$[-0.732,-0.048]$} & {$[-0.66,0.082]$} \\
\hline \multirow[t]{2}{*}{ Group size } & 0.005 & 0.005 & 0.005 & 0.005 & 0.005 \\
\hline & {$[-0.005,0.017]$} & {$[-0.005,0.017]$} & {$[-0.005,0.017]$} & {$[-0.005,0.017]$} & {$[-0.005,0.017]$} \\
\hline
\end{tabular}

Conditional fits of categorical variables

\begin{tabular}{llll}
\hline & 0 & 1 & \\
\hline Mayor & 0.808 & 0.798 & \\
ENA & {$[0.792,0.826]$} & {$[0.783,0.813]$} & \\
& 0.798 & 0.797 & \\
Majority & {$[0.784,0.812]$} & {$[0.784,0.812]$} & \\
& 0.798 & 0.798 & \\
Woman & {$[0.784,0.812]$} & {$[0.784,0.812]$} & \\
& 0.798 & 0.802 & \\
First year & {$[0.784,0.812]$} & {$[0.788,0.817]$} & \\
& 0.798 & $0.72^{*}$ & \\
& {$[0.785,0.812]$} & {$[0.699,0.742]$} & \\
& & & \\
& Left & Neutral & 0.793 \\
\hline Left-Right & 0.798 & 0.777 & {$[0.779,0.806]$} \\
\hline Region dummies & {$[0.783,0.812]$} & {$[0.761,0.794]$} & \\
Occupation dummies & Included & & \\
Committee dummies & Included & & \\
\hline R-squared & 0.730 & & \\
Observations & 20867 & & \\
\hline
\end{tabular}

${ }^{*} p<0.05$ 


\subsection{Controlling for reverse causality: the freshman subsam- ple}

The results from the base model might suffer from an endogeneity problem. In the case of deputies running for reelection, the lagged measure of competition might be influenced by the unobservable characteristics of those deputies. As they were already in office and taking part in the political competition, their personal characteristics might have affected the degree of competition, implying a potential reverse causality issue: it is because 'good' politicians are running in a district that competition is tight, and not the opposite as we claim.

To mitigate this issue and considering the lack of instrumental variables available, we restrict our sample to deputies being elected for the first time, for a total of more than 7,500 observations. Results are presented in Figure 2 and Table 4. The positive and linear relationship between electoral competition and activity still holds in this context. Despite the reduced number of observations in the sample, the confidence intervals are much narrower, reinforcing the relationship between electoral competition and activity. The increasing activity over time is also observed in this subsample, even with the model including year dummies instead of legislature ones (see Appendix A).

Concerning control variables, most of the results obtained with the whole sample are confirmed. Schooling is again strongly and positively correlated with activity, and age has a negative increasing impact for the oldest deputies. Experience might in very few cases take high values since we consider the first mandate of a deputy after his/her election, and some of them previously worked in the Parliament as substitutes. The size of the political group is negatively correlated with activity for small groups, but its impact becomes positive as the size of the group increases. For the categorical variables, all the sign of correlations are preserved with respect to the full sample. All these results are robust to the alternative specification which replaces the legislature variable by a year variable (see Appendix C). 
Table 5: Control variables - Freshmen sample

\begin{tabular}{|c|c|c|c|c|c|}
\hline & Median & Min. & $25 \%$ & $75 \%$ & Max. \\
\hline \multicolumn{6}{|c|}{ Gradients of continuous variables } \\
\hline \multirow[t]{2}{*}{ Schooling } & $1.562^{*}$ & $1.562^{*}$ & $1.562^{*}$ & $1.562^{*}$ & $1.562^{*}$ \\
\hline & {$[0.969,2.189]$} & {$[0.969,2.189]$} & {$[0.969,2.189]$} & {$[0.969,2.189]$} & {$[0.969,2.189]$} \\
\hline \multirow[t]{2}{*}{ Age } & -0.105 & 0.082 & 0.018 & $-0.299^{*}$ & $-0.541^{*}$ \\
\hline & {$[-0.298,0.105]$} & {$[-0.14,0.316]$} & {$[-0.169,0.222]$} & {$[-0.546,-0.039]$} & {$[-0.875,-0.203]$} \\
\hline \multirow[t]{2}{*}{ Experience } & $1.138^{*}$ & $2.009^{*}$ & $1.488^{*}$ & $0.863^{*}$ & 0.562 \\
\hline & {$[0.447,1.783]$} & {$[1.117,2.83]$} & {$[0.74,2.172]$} & {$[0.174,1.509]$} & {$[-0.103,1.171]$} \\
\hline \multirow[t]{2}{*}{ Group size } & -0.005 & $-0.051^{*}$ & $-0.028^{*}$ & $0.018^{*}$ & $0.042^{*}$ \\
\hline & {$[-0.02,0.01]$} & {$[-0.069,-0.035]$} & {$[-0.042,-0.013]$} & {$[0.003,0.035]$} & {$[0.025,0.061]$} \\
\hline \multicolumn{6}{|c|}{ Conditional fits of categorical variables } \\
\hline & 0 & 1 & & & \\
\hline \multirow[t]{2}{*}{ Mayor } & 0.808 & 0.795 & & & \\
\hline & {$[0.793,0.825]$} & {$[0.779,0.812]$} & & & \\
\hline \multirow[t]{2}{*}{ ENA } & 0.795 & 0.795 & & & \\
\hline & {$[0.778,0.813]$} & {$[0.778,0.813]$} & & & \\
\hline \multirow[t]{2}{*}{ Majority } & 0.795 & 0.795 & & & \\
\hline & {$[0.778,0.813]$} & {$[0.778,0.813]$} & & & \\
\hline \multirow[t]{2}{*}{ Woman } & 0.795 & 0.797 & & & \\
\hline & {$[0.777,0.814]$} & {$[0.779,0.816]$} & & & \\
\hline \multirow[t]{3}{*}{ First year } & 0.795 & $0.729^{*}$ & & & \\
\hline & {$[0.779,0.813]$} & {$[0.703,0.755]$} & & & \\
\hline & Left & Neutral & Right & & \\
\hline \multirow[t]{2}{*}{ Left-Right } & 0.795 & 0.771 & 0.788 & & \\
\hline & {$[0.779,0.814]$} & {$[0.752,0.789]$} & {$[0.772,0.807]$} & & \\
\hline Region dummies & Included & & & & \\
\hline Occupation dummies & Included & & & & \\
\hline Committee dummies & Included & & & & \\
\hline R-squared & 0.696 & & & & \\
\hline Observations & 7509 & & & & \\
\hline
\end{tabular}

\subsection{Disentangling selection from incentives}

To make sure that the observed positive relation between electoral competition and the activity-based measure of quality is driven by selection, we need to consider that 
this relation can be alternatively driven by reelection incentives. This would mean that deputies elected in highly contested districts reach a higher activity in order to 'look good' to voters and increase their reelection probability. As explained in Section 3, the organization of the political group limits this alternative explanation since our measure of activity does not only depend on effort. To further rule out this mechanism, we proceed as Galasso and Nannicini (2011) by including in the model a measure of the future degree of competition and using a subsample containing the last year of legislatures to account for the fact that incentives are at their maximum during the preelectoral year. We further restrict the sample to legislatures during which an exogenous shock significantly impacted the degree of competition for the upcoming elections (detailed below). Finally, only deputies running for reelection face such incentives. Deputies not running for legislative elections are hence excluded.

The future degree of electoral competition is approximated by the Herfindahl index of the upcoming elections. We gather additional information about the decision to run again or not from the official lists of candidates provided by the Ministry of Interior. This information is only available for the period 1988-2012 ${ }^{26}$. During this period, we identify two exogenous shocks that are likely to have affected the degree of competition in all constituencies. First, the 1993 elections have been held just after a series of political scandals, involving the President of the National Assembly as well as ministers, provoking a collapse of the leftist coalition, while disagreement concerning the Maastricht treaty divided the right wing (Chevallier et al., 2012). Second, the creation of the $U M P$ for the 2002 presidential election, aiming at unifying the right wing, drastically modified the landscape of French politics (Chevallier et al., 2012). Focusing on the deputies running for reelection in 1992 and 2001 yields 851 observations.

Results for ex ante competition and future competition are provided in Figure $5^{27}$. They indicate that even when we control for reelection incentives, the ex ante competition is still positively correlated with activity. On the other hand, the contestability of the upcoming elections is even negatively related to the activity in the

\footnotetext{
${ }^{26}$ The name of candidates do not appear on election results provided by the Ministry of Interior before this date, only the name of the party. It is thus not possible to know if a deputy who leaves his/her seat ran for reelection and lost or decided not to run.

${ }^{27}$ We present here only results for these two variables. Results for the other explanatory variables remain stable, and are available upon request.
} 
last year of a legislature. This can be explained by the fact that candidates expecting a tight competition spend more time campaigning in their constituency during the last year of a legislature ceteris paribus ${ }^{28}$

Figure 5: Reelection incentives

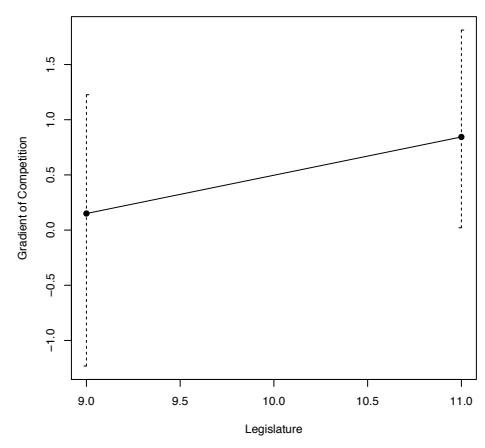

(a) Ex ante competition

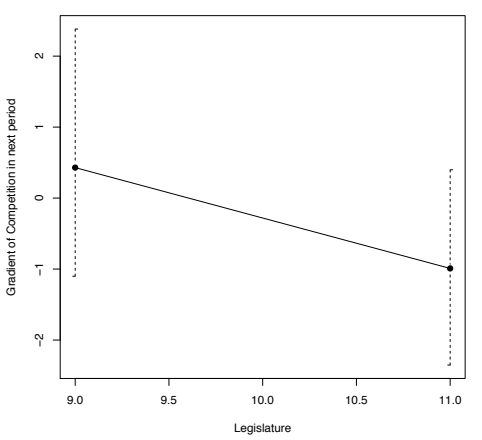

(b) Future competition

\subsection{Variation of the relationship over time}

An interesting feature of the nonparametric approach is that it allows for interactions between variables in the most flexible way, enabling us to observe how the positive relationship between electoral competition and political selection evolves over time. In other words we can test the validity of the Galasso and Nannicini (2011) model in a temporal perspective. Figure 6 shows the impact of competition depending on legislatures using the whole sample. The dotted lines indicate the confidence interval at the $95 \%$ level. It indicates a clear inverse-U shape: the effect of electoral competition sharply increased till the $I X^{\text {th }}$ legislature, i.e., the 1988 elections, but it has decreased since then, and it has become insignificant since the $X I^{\text {th }}$ legislature.

When restricted to the freshmen subsample, results are similar. The inverse- $U$ shape is even clearer when we replace the legislature variable by the year variable

\footnotetext{
${ }^{28}$ As the number of observations is relatively small for a nonparametric investigation, we implemented a GAM semiparametric model as well as a standard parametric model estimated with OLS. Both indicate a significant positive impact of ex ante competition together with a negative impact of future competition. Results are available upon request.
} 
for the whole sample. Electoral competition exerts its highest impact in the 80's, which corresponds to the period between the $V I I^{t h}$ and the $I X^{t h}$ legislatures. For the freshmen deputies in this setting, the results are not as clear, but the highest impact of electoral competition is also achieved in the 80's, in accordance with the previous results. In these two settings, competition never plays a negative role, but as previously, the effect of ex ante competition turns insignificant in the most recent years.

To explain this pattern, we present three elements ${ }^{29}$. As explained in Section 3, the 1980s were a turning point. First, the relative convergence of political parties on the left/right scale is supposed to have increased the volatility of voters. If at first sight it indicates an increase in the share of neutral voters, hence intensifying the relationship between competition and activity, this is however not necessarily the case. Instead of moving from partisanship to neutrality, it is possible that supporters of a party $A$ at election $t$ turn into supporters of party $B$ at election $t+1$. Partisans disappointed by the behavior of their party while in office might provide an unconditional support to the competing party at the next election. This is consistant with the fact that not any party succeeded to win two national elections in a row since the 80 's. This mechanism might moreover have hampered the efficiency of the candidate allocation process of political parties, as suggested by Knapp (2002).

Second, the selection mechanism might have been further weakened due to both the move toward the decentralization of the selection process (Hazan and Rahat, 2010) and to the shrinking pool of potential candidates due to the decreasing party membership (Knapp, 2002). These two phenomena also tend to drift away the context from the theoretical model, providing support to the mechanism that it describes. Third, the 'bipolar quadrille', i.e. the context in the 70's during which the two political wings were each represented by two parties of equal importance, ended with the election of François Mitterrand in 1981, slightly shifting away the political context from the strict two-party competition described in the theoretical model. It is thus interesting to note that it is during this particular situation that the intensity of the competition/activity relation reached its maximum.

\footnotetext{
${ }^{29}$ Formally testing the relevance of these explanations is out of the scope of this paper. Rather we aim at providing some direction for future work.
} 
Figure 6: Effect of competition over time

\section{Effect of Competition over legislatures}

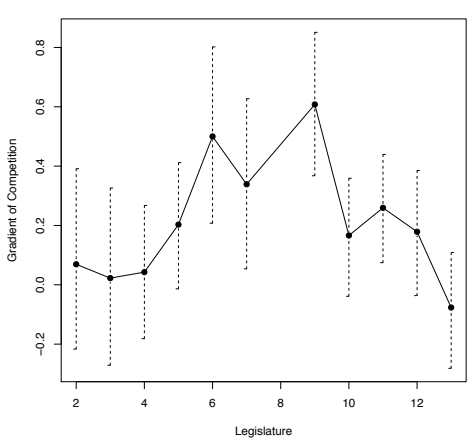

(a) Full sample

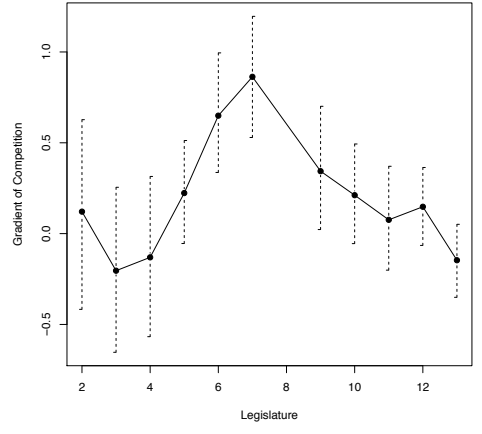

(b) Freshmen sample

Effect of Competition over years

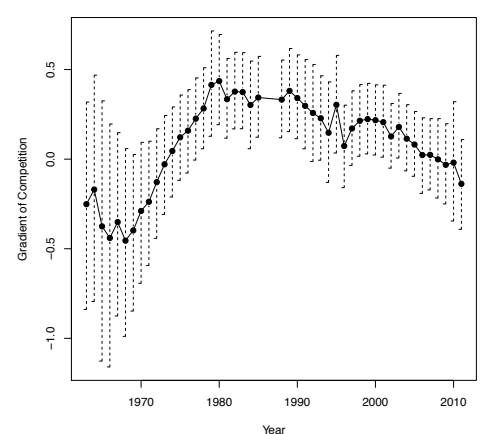

(c) Full sample

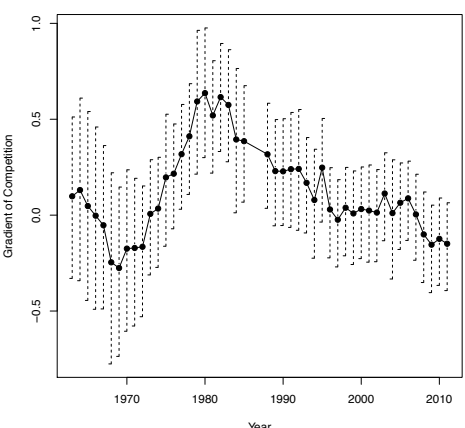

(d) Freshmen sample

\section{Conclusion}

Since politicians may differ in their quality, one needs to identify the drivers of an efficient selection mechanism. This paper investigated the relationship between electoral competition and political selection. To this purpose we constructed an original dataset encompassing detailed information about more than 2,400 deputies of the French Assemblée Nationale from 1958 to 2012, including their individual work within the Parliament as well as personal characteristics on a yearly basis. 
Our first task has been to develop a measure of quality based on the parliamentary activity of each deputy. To do so, we used a robust nonparametric efficiency method based on dominance, the $\alpha$-efficiency estimator. Because individual parliamentary activity reflects both effort and competence, this measure of quality is much more precise that what has previously been used in the literature. We then constructed a measure of electoral competition based on a Herfindahl index, fitting both the French institutional and political framework and the theoretical framework provided by Galasso and Nannicini (2011).

We used a nonparametric kernel regression model allowing for non-linearity and interaction effects, providing full flexibility. The estimated models, controlling for various factors likely to influence parliamentary activity, point out a clear positive relationship between electoral competition and political selection. Deputies elected in a priori contested districts tend to perform better than others. This result is robust to alternative model specifications. To ensure that this finding is driven by a selection and not by a reelection incentive effect, we control in a separate analysis for reelection perspectives. Interestingly and as suggested by the literature, we also obtained a positive effect of education. The nonparametric approach allows us to observe how the relationship between electoral competition and political selection evolved over time. Since ideologies tend to convergence over time, we expected the relationship to gain in intensity. This is however not the case. The impact of competition increased till the 80's, but continuously decreases since then, even if it remains positive.

This opens the door for a vast research agenda. First, despite a progress compared to the previous literature, our proxy for quality is still not a panacea. Introducing in the analysis a -direct- qualitative assessment of politicians' work remain to be done. Our context does not allow such an extension, but there should be other context allowing for that kind of investigation. Second, our results however indicate that drivers of an efficient selection mechanism are not necessarily stable over time. Both theoretical and empirical work is needed to better understand under which conditions political competition enhances political selection. Finally, the literature identified some other factors impacting political selection, such as politicians' wage. This asks the question whether those other factors have a time varying relationship with political selection as well. 


\section{Acknowledgements}

We would like to thank two anonymous editors, Elise Brezis, Laurens Cherchye, Bram De Rock, Fabio Padovano, two anonymous referees and participants at the seminar at the University of Leuven in Kortrijk, at the European Public Choice Society meeting 2015 and at the annual meeting of the French Economic Association 2015 for their insightful comments and suggestions. We also thank Dominique Anglès d'Auriac from the Archive department of the Assemblée Nationale. The usual caveats apply.

\section{References}

Acemoglu, D., Egorov, G., Sonin, K., 2010. Political selection and persistence of bad government. Quarterly Journal of Economics 125 (4), 1511-1575.

Aitchison, J., Aitken, C. G. G., 1976. Multivariate binary discrimination by kernel method. Biometrika 63 (3), 413-420.

Aragon, Y., Daouia, A., Thomas-Agnan, C., 2006. Efficiency measurement: a nonparametric approach. Annales d'économie et de statistique 82, 217-242.

Ashworth, J., Geys, B., Heyndels, B., Wille, F., 2014. Competition in the political arena and local government performance. Applied Economics, 46 (19), 2264-2276.

Avril, P., 2005.Qui fait la loi? Pouvoirs 114, 89-99.

Bach, L., 2011. Should multiple office-holding be forbidden to politicians? Evidence from France. Mimeo working paper.

Balaguer-Coll, M. T., Prior, D., Tortosa-Ausina, E., 2007. On the determinants of local government performance: A two-stage nonparametric approach. European Economic Review, 51(2), 425-451.

Baltrunaite, A., Bello, P., Casarico, A., Profeta, P., 2014. Gender quotas and the quality of politicians. Journal of Public Economics 118, 62-74.

Becker, G. S., 1983. A theory of competition among pressure groups for political influence. Quarterly Journal of Economics 97, 371-400. 
Becker, J., Peichl, A., Rincke, J., 2009. Politicians' outside earning and electoral competition. Public Choice 140, 379-394.

Bénabou, R., Tirole, J., 2003. Intrinsic and extrinsic motivation. Review of Economic Studies 70 (3), 469-520.

Besley, T., 2004. Paying politicians: theory and evidence. Journal of the European Economic Association 2 (2-3), 193-215.

Besley, T., 2006. Principled agents? The political economy of good government. Oxford University Press.

Besley, T., Coate, S., 1997. An economic model of representative democracy. Quarterly Journal of Economics, 85-114.

Besley, T., Folke, O., Persson, T., Rickne, J., 2013. Gender quotas and the crisis of the mediocre man: Theory and evidence from sweden. IFN Working Paper 985.

Besley, T., Montalvo, J., Reynal-Querol, M., 2011. Do educated leaders matter? Economic Journal 121, 205-227.

Besley, T., Pande, R., Rao, V., 2005. Political selection and the quality of government: Evidence from south india. PEPP/8, Suntory and Toyota International Centres for Economics and Related Disciplines, London School of Economics and Political Science, London, UK.

Besley, T., Persson, T., Sturm, D., 2010. Political competition, policy and growth: Theory and evidence from the us. Review of Economic Studies 77, 1329-1352.

Besley, T., Preston, I., 2007. Electoral bias and policy choice: Theory and evidence. Quarterly Journal of Economics 122 (4), 1473-1510.

Best, H., Cotta, M., 2000. Parliamentary Representatives in Europe 1848- 2000. Oxford University Press.

Brouard, S., Costa, T., Konig, T., 2012. Are French Laws Written in Brussels ? Beyond the "Delors Myth", the limited europeanization of lawmaking in France and its implications, in The Europeanization of Domestic Legislatures: The Empirical Implications of the Delors' Myth in Nine Countries, Springer, 75-93. 
Caillaud, B., Tirole, J., 2002. Parties as political intermediaries. Quarterly Journal of Economics 117 (4), 1453-1489.

Carcassonne, G., 1989. Réhabiliter le Parlement. Pouvoirs 49, 37-45.

Carcassonne, G., 1993. De la démocratie au Parlement. Pouvoirs 64, 35-41.

Carrillo, J. D., Mariotti, T., 2001. Electoral competition and politicians turnover. European Economic Review 45, 1-25.

Cazals, C., Florens, J. P., Simar, L., 2002. Nonparametric frontier estimation: A robust approach. Journal of Econometrics 106 (1), 1-25.

Cherchye, L., Lovell, C.A.K., Moesen, W., Van Puyenbroeck, T., 2007. One market, one number? A composite indicator assessment of EU internal market dynamics. European Economic Review, 51, 749-779.

Cherchye, L., Demuynck, T., De Rock, B., De Witte, K., 2014. Non-parametric Analysis of Multi-output Production with Joint Inputs. The Economic Journal, 124 (577), 735-775.

Cherchye, L., De Rock, B., Dierynck, B., Roodhooft, F., Sabbe, J., 2013. Opening the "black box" of efficiency measurement: input allocation in multioutput settings. Operations research, 61 (5), 1148-1165.

Chevallier, J. J., Carcassonne, G., Duhamel, O., 2012. Histoire de la Ve République: 1958-2012. Dalloz.

Crain, M. W., Tollison, R. D., 1982. Team production in political majorities. Micropolitics 2, 111-121.

Daraio, C., Simar, L., 2007. Advanced robust and nonparametric methods in efficiency analysis: methodology and applications. Springer Science and Business Media.

Davin, J. P., 1985. Les groupes parlementaires. Pouvoirs 34, 23-29.

De Paola, M., Scoppa, V., 2011. Political competition and politician quality: Evidence from italian municipalities. Public Choice 148, 547-559. 
Deaton, A., 1989. Rice prices and income distribution in thailand: a non-parametric analysis. The Economic Journal, 1-37.

Dreher, A., Lamla, M., Lein, S., Somogyi, F., 2009. The impact of political leaders' profession and education on reforms. Journal of Comparative Economics 37, 169193.

Drummond, A. J., 2006. Electoral volatility and party decline in western democracies: 1970-1995. Political Studies 54 (3), 628-647.

Duverger, M., 1973. Un quadrille bipolaire. Le Monde 15/03/1973.

François, A., Weill, L., 2014. Le cumul de mandats locaux affecte-t-il l'activité des députés français? Revue économique 65 (6), 881-906.

Fried, H., Lovell, C., Schmidt, S., 2008. Efficiency and productivity. The measurement of productive efficiency and productivity growth, 3-91.

Gagliarducci, S., Nannicini, T., 2013. Do better paid politicians perform better? disentangling incentives from selection. Journal of the European Economic Association 11 (2), 369-398.

Galasso, V., Nannicini, T., 2011. Competing on good politicians. American Political Science Review 105 (1), 79-99.

Gavoille, N., 2014. The deputies of the fifth french republic: a database (1958-2012). Condorcet Center for Political Economy working paper.

Green, J., 2007. When voters and parties agree: Valence issues and party competition. Political Studies 55, 629-655.

Haavelmo, T., 1944. The probability approach in econometrics. Econometrica 12, iii-115.

Hall, P., Li, Q., Racine, J. S., 2007. Nonparametric estimation of regression functions in the presence of irrelevant regressors. Review of Economics and Statistics 89 (4), 784-789.

Hazan, R. Y., Rahat, G., 2010. Democracy within parties. Oxford University Press. 
Hayfield, T., Racine, J. S., 2008. Nonparametric econometrics: The np package. Journal of Statistical Software, 27 (5).URL http://www.jstatsoft.org/v27/i05/.

Henderson, D. J., Kumbhakar, S. C., 2006. Public and private capital productivity puzzle: A nonparametric approach. Southern Economic Journal 73 (1), 219-232.

Henderson, D. J., Papageorgiou, C., Parmeter, C. F., 2013, Who benefits from financial development? New methods, new evidence. European Economic Review, $63,47-67$.

Henderson, D. J., Parmeter, C. F., 2015, Applied nonparametric econometrics. Cambridge University Press.

Jones, B., Olken, B., 2005. Do leaders matter? National leadership and growth since world war II. Quarterly Journal of Economics 120 (3), 835-864.

Knapp, A., 2002. Political parties in advanced industrial democracies. Oxford, Ch. France: Never a golden age, pp. 107-150.

Knapp, A., Wright, V., 2001. The government and politics of France. Routledge.

Koopmans, T. C., 1951. Analysis of production as an efficient combination of activities, in T.C. Koopmans, ed., Activity Analysis of Production and Allocation. New York: John Wiley \& Sons.

Kotakorpi, K., Poutvaara, P., 2011. Pay for politicians and candidate selection: An empirical analysis. Journal of Public Economics 95, 877-885.

Larcinese, V., 2014. Enfranchisement and representation: Evidence from the introduction of quasi-universal suffrage in italy. Innocenzo Gasparini Institute for Economic Research working paper series.

Lewis-Beck, M., 1997. Who's the chef? Economic voting under a dual executive. European Journal of Political Research 31 (3), 315-325.

Li, Q., Racine, J., 2004. Cross-validated local linear nonparametric regression. Statistica Sinica 14 (2), 485-512.

Li, Q., Racine, J., 2007. Nonparametric Econometrics: Theory and practice. Princeton University Press. 
Lundell, K., 20014. Determinants of candidate selection: The degree of centralization in comparative perspective. Party Politics 10 (1), 25-47.

Mattozzi, A., Merlo, A., 2007. The transparency of politics and the quality of politicians. American Economic Review 97 (2), 311-315.

Mattozzi, A., Merlo, A., 2008. Political careers or career politicians? Journal of Public Economics 92 (3-4), 597-608.

Mattozzi, A., Merlo, A., 2010. Mediocracy. PIER working paper 13-010.

Mayer, N., Perrineau, P., 1992. Why do they vote for Le Pen? European Journal of Political Research 22 (1), 123-141.

Melyn, W., Moesen, W., 1991. Towards a synthetic indicator of macroeconomic performance: Unequal weighting when limited information is available. Public Economics Research Paper 17, Centre for Economic Studies, Leuven.

Messner, M., Polborn, M., 2004. Paying politicians. Journal of Public Economics 88, 2423-2445.

Osborne, M. J., Slivinski, A., 1996. A model of political competition with citizencandidates. Quarterly Journal of Economics, 65-96.

Padovano, F., Gavoille, N., 2014. Legislative cycles in semipresidential systems. Condorcet Center for Political Economy working paper.

Padovano, F., Ricciuti, R., 2009. Political competition and economic performance: Evidence from italian regions. Public Choice 138, 263-277.

Poutvaara, P., Takalo, T., 2007. Candidate quality. International Tax and Public Finance 14, 7-27.

Racine, J., Li, Q., 2004. Nonparametric estimation of regression functions with both categorical and continuous data. Journal of Econometrics 119 (1), 99-130.

Rogers, J. R., 2002. Free riding in state legislature. Public Choice 113, 59-76.

Shugart, M. S., 2005. Semi-presidential systems: Dual executive and mixed authority patterns. French Politics 3, 323-351. 
Skilling, D., Zeckhauser, R. J., 2002. Political competition and debt trajectories in japan and the oecd. Japan and the World Economy 14, 121-135.

Solé-Ollé, A., 2006. The effects of party competition on budget outcomes: Empirical evidence from local government in spain. Public Choice 126, 145-176.

Solé-Ollé, A., Viladecans-Marsal, E., 2012. Lobbying, political competition, and local land supply: Recent evidence from spain. Journal of Public Economics, 10-19.

Stigler, G., 1972. Economic competition and political competition. Public Choice 13, 91-106.

Thiébault, J. L., 1988. Candidate selection in perspective: The secret garden of politics. Sage, Ch. France: The impact of electoral system change, pp. 73-95.

Thiébault, J. L., Dolez, B., 1988. Parliamentary parties in the French Fifth Republic, in Parliamentary party groups in European democracies. Routledge, 57-70.

Tulkens, H., 2006. Public goods, environmental externalities and fiscal competition. Springer US, Ch. Efficiency Dominance Analysis (EDA): Basic Methodology, 431442.

Wang, M. C., van Ryzin, J., 1981. A class of smooth estimators for discretedistributions. Biometrika 68 (1), 301-309.

Yatchew, A., 1998. Nonparametric regression techniques in economics. Journal of Economic Literature 36, 669-721.

Ysmal, C., 1994. The history of electoral studies in france. European Journal of Political Research 25 (3), 367-385. 


\section{Appendix A}

This appendix provides the results of the non parametric model using year instead of legislature as time-effect.

Table A1: Control variables - Full sample and years

\begin{tabular}{|c|c|c|c|c|c|}
\hline & Median & Min. & $25 \%$ & $75 \%$ & Max. \\
\hline \multicolumn{6}{|c|}{ Gradients of continuous variables } \\
\hline \multirow[t]{2}{*}{ Schooling } & $1.975^{*}$ & $1.975^{*}$ & $1.975^{*}$ & $1.975^{*}$ & $1.975^{*}$ \\
\hline & {$[1.122,2.83]$} & {$[1.122,2.83]$} & {$[1.122,2.83]$} & {$[1.122,2.83]$} & {$[1.122,2.83]$} \\
\hline \multirow[t]{2}{*}{ Age } & -0.131 & 0.091 & 0.005 & $-0.314^{*}$ & $-0.528^{*}$ \\
\hline & {$[-0.378,0.121]$} & {$[-0.134,0.312]$} & {$[-0.225,0.237]$} & {$[-0.583,-0.039]$} & {$[-0.821,-0.23]$} \\
\hline \multirow[t]{2}{*}{ Experience } & $-0.399^{*}$ & $-0.399^{*}$ & $-0.399^{*}$ & $-0.399^{*}$ & $-0.399 *$ \\
\hline & {$[-0.718,-0.099]$} & {$[-0.718,-0.099]$} & {$[-0.718,-0.099]$} & {$[-0.718,-0.099]$} & {$[-0.718,-0.099]$} \\
\hline \multirow[t]{2}{*}{ Group size } & 0.015 & $-0.058^{*}$ & $-0.016^{*}$ & $0.042^{*}$ & $0.059^{*}$ \\
\hline & {$[-0.004,0.036]$} & {$[-0.072,-0.043]$} & {$[-0.03,-0.001]$} & {$[0.017,0.068]$} & {$[0.029,0.091]$} \\
\hline \multicolumn{6}{|c|}{ Conditional fits of categorical variables } \\
\hline & 0 & 1 & & & \\
\hline \multirow[t]{2}{*}{ Mayor } & 0.801 & 0.777 & & & \\
\hline & {$[0.783,0.822]$} & {$[0.747,0.808]$} & & & \\
\hline \multirow[t]{2}{*}{ ENA } & 0.777 & 0.777 & & & \\
\hline & {$[0.75,0.804]$} & {$[0.752,0.803]$} & & & \\
\hline \multirow[t]{2}{*}{ Majority } & 0.77 & 0.777 & & & \\
\hline & {$[0.736,0.802]$} & {$[0.75,0.805]$} & & & \\
\hline \multirow[t]{2}{*}{ Woman } & 0.777 & 0.78 & & & \\
\hline & {$[0.749,0.808]$} & {$[0.752,0.81]$} & & & \\
\hline \multirow[t]{3}{*}{ First year } & 0.777 & 0.725 & & & \\
\hline & {$[0.75,0.804]$} & {$[0.699,0.751]$} & & & \\
\hline & Left & Neutral & Right & & \\
\hline \multirow[t]{2}{*}{ Left-Right } & 0.777 & 0.775 & 0.79 & & \\
\hline & {$[0.748,0.806]$} & {$[0.756,0.793]$} & {$[0.77,0.811]$} & & \\
\hline Region dummies & Included & & & & \\
\hline Occupation dummies & Included & & & & \\
\hline Committee dummies & Included & & & & \\
\hline R-squared & 0.789 & & & & \\
\hline Observations & 20867 & & & & \\
\hline
\end{tabular}

${ }^{*} p<0.05$ 
Table A2: Control variables - Freshmen sample and years

\begin{tabular}{|c|c|c|c|c|c|}
\hline & Median & Min. & $25 \%$ & $75 \%$ & Max. \\
\hline \multicolumn{6}{|c|}{ Gradients of continuous variables } \\
\hline \multirow[t]{2}{*}{ Schooling } & $1.379^{*}$ & $2.051^{*}$ & $1.7^{*}$ & $1.062^{*}$ & $0.742^{*}$ \\
\hline & {$[0.703,2.064]$} & {$[1.117,2.965]$} & {$[0.915,2.475]$} & {$[0.462,1.694]$} & {$[0.181,1.354]$} \\
\hline \multirow[t]{2}{*}{ Age } & -0.069 & 0.148 & 0.073 & -0.286 & $-0.542^{*}$ \\
\hline & {$[-0.302,0.18]$} & {$[-0.177,0.451]$} & {$[-0.169,0.318]$} & {$[-0.59,0.038]$} & {$[-0.955,-0.101]$} \\
\hline \multirow[t]{2}{*}{ Experience } & $1.938^{*}$ & $1.938^{*}$ & $1.938^{*}$ & $1.938^{*}$ & $1.938^{*}$ \\
\hline & {$[1.123,2.709]$} & {$[1.123,2.709]$} & {$[1.123,2.709]$} & {$[1.123,2.709]$} & {$[1.123,2.709]$} \\
\hline \multirow[t]{2}{*}{ Group size } & -0.003 & -0.01 & -0.007 & 0.001 & 0.005 \\
\hline & {$[-0.016,0.011]$} & {$[-0.023,0.002]$} & {$[-0.02,0.006]$} & {$[-0.013,0.015]$} & {$[-0.009,0.02]$} \\
\hline \multicolumn{6}{|c|}{ Conditional fits of categorical variables } \\
\hline & 0 & 1 & & & \\
\hline \multirow[t]{2}{*}{ Mayor } & 0.812 & 0.81 & & & \\
\hline & {$[0.794,0.83]$} & {$[0.792,0.829]$} & & & \\
\hline \multirow[t]{2}{*}{ ENA } & 0.81 & 0.797 & & & \\
\hline & {$[0.79,0.831]$} & {$[0.756,0.849]$} & & & \\
\hline \multirow[t]{2}{*}{ Majority } & 0.81 & 0.81 & & & \\
\hline & {$[0.791,0.828]$} & {$[0.791,0.828]$} & & & \\
\hline \multirow[t]{2}{*}{ Woman } & 0.81 & 0.815 & & & \\
\hline & {$[0.792,0.83]$} & {$[0.786,0.847]$} & & & \\
\hline \multirow[t]{3}{*}{ First year } & 0.81 & $0.755^{*}$ & & & \\
\hline & {$[0.794,0.828]$} & {$[0.73,0.78]$} & & & \\
\hline & Left & Neutral & Right & & \\
\hline \multirow[t]{2}{*}{ Left-Right } & 0.81 & 0.78 & 0.803 & & \\
\hline & {$[0.79,0.83]$} & {$[0.76,0.8]$} & {$[0.786,0.821]$} & & \\
\hline Region dummies & Included & & & & \\
\hline Occupation dummies & Included & & & & \\
\hline Committee dummies & Included & & & & \\
\hline R-squared & 0.767 & & & & \\
\hline Observations & 7509 & & & & \\
\hline
\end{tabular}


Figure A1: Year model

\section{Conditional activity over years}

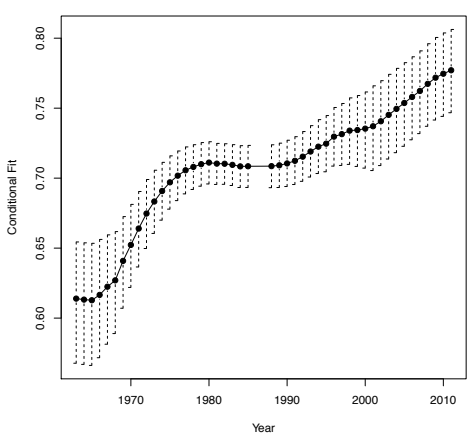

(a) Full sample

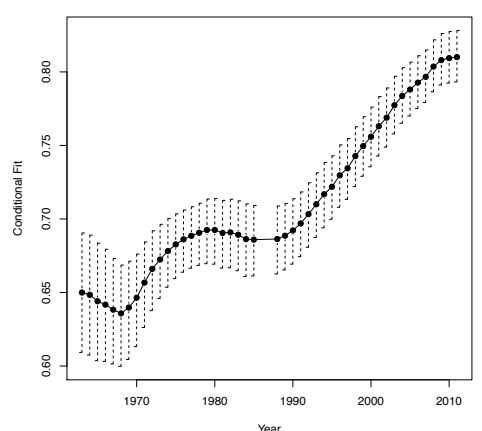

(b) Freshmen sample

\section{Effect of Competition}

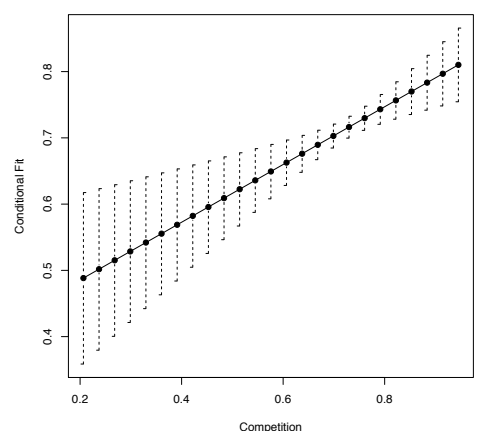

(c) Full sample

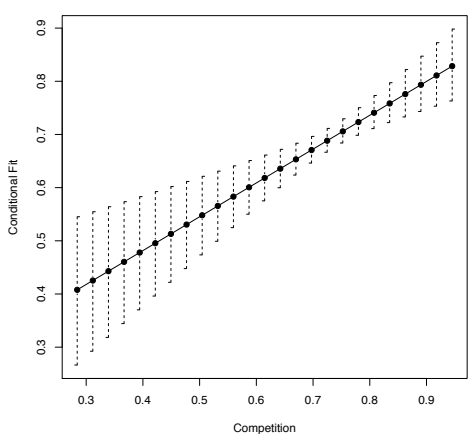

(d) Freshmen sample 


\section{Appendix B}

This appendix provides a sensitivity analysis on the used estimation methodology. Overall, our results are robust for altering the estimation methodology. In particular, we reproduced our analysis using a standard parametric model fitted with OLS.

For the evolution of the link between activity and competition over time, we find only weak evidence of an inverse- $U$ relationship when we introduce an interaction term between competition and legislature dummies. The reason is that in the nonparametric framework, the successive legislatures are considered as one ordered categorical variable, thus taking the natural order of legislatures into account, a feature that dummies cannot provide (see Henderson and Parmeter, 2015, p. 189-190 for a discussion of smoothing ordered discrete variables). However, if we simplify the model by reducing the number of dummies and interactions, results support the nonparametric findings. In particular, we introduced interactions between competition and three legislature groups: a group encompassing legislature 2-5, a group for legislature 6-9, and a third group for legislatures higher than 9. With this specification, as shown Figure B1, we obtain results confirming the findings from the nonparametric counterpart of a clear inverse- $\mathrm{U}$ relationship.

Table B1: Activity and political competition - OLS

\begin{tabular}{rr}
\hline Endogenous : & Activity \\
\hline Competition & $\begin{array}{r}0.110^{* *} \\
(0.003)\end{array}$ \\
\hline Controls & Yes \\
\hline R-squared & 0.167 \\
Observations & 4151 \\
\hline${ }^{*} p<0.05$ &
\end{tabular}


Figure B1: Effect of competition over legislature - OLS

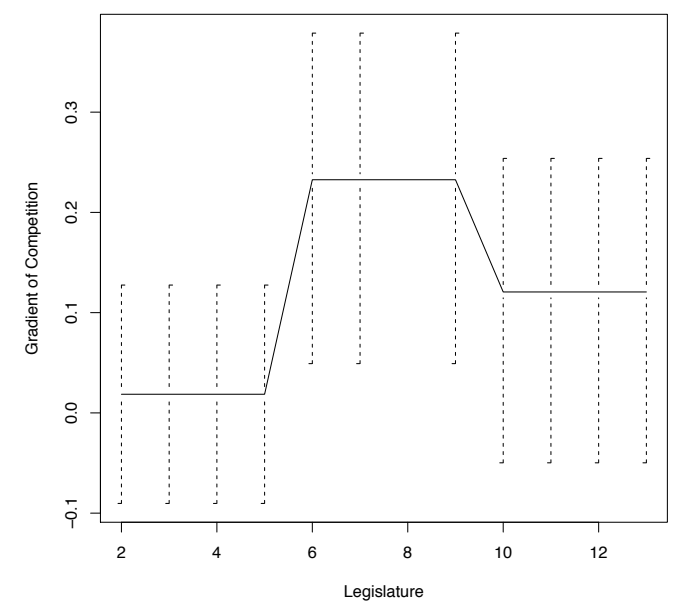

